\title{
特発性腎出血の病理組織学的研究
}

\author{
金沢大学医学部泌尿器科教室 大学院学生 長 谷 川 真 常
(主任:喜田教授)
}

\section{A HISTOPATHOLOGICAL STUDY OF ESSENTIAL RENAL HEMATURIA}

\author{
Masatsune Hasegawa \\ From the Department of Urology, School of Medicine, Kanazawa University \\ (Director: Prof, K. Kuroda)
}

Before making a histopathological study of essential renal hematuria, the author researched the structure of vessels about the renal calyces, which were obtained by injecting acryc resin into renal arteries. As a result, it was found that in the renal calyces there are the spiral arteries, which are branched off interlobar arteries.

The author made researches in the nine removed kidneys. They were all diagnosed essential renal hematuria, and had resistance to various conservative treatments. They were observed as serial sections, contained renal parenchyma, calyx and pelvis together in one section. And there were used such stains as Hematoxylin-Eosin, Masson's Trichrome, etc.

The findings are as follows. The bleeding region is the renal calyces in all cases. And moreover, the bleeding appeared at medulla, especially about cortico-medullary junction in five cases. At region of calcium plaque ablation in papillary apex, and the localized glomerular bleeding was accompanied at cortex in one case. In all cases, each kidney had hemorrhagic change in one or two calyces, although there was no special localization. And moreover, spiral artery showed the marked sclerotic change at those damaged calyces. On the other hand, remarkable congestions tendency was observed in the renal vessels everywhere; particularly calyx-wall showed the dilatation of capillaries, hemorrhagia per diapedesin, and early stage of granulation. As a more interestıng view ie calyx-wall, having hard degeneration of the spiral artery, there were remarkably seen sclerosis of connective tissue and atrophic degeneration of the smooth muscle fibers. Consequently the calyx-wall gren thin, and at the same time, fissure of tissue (hemorrhagia per rhexin of capillaries) were observed at calyx-papilla angle and so on.

Judging from the above histological findings and literatures, the following is considered to be important.

One of etiological factors of essential hematuria exists in Locus minoris resistentiae. It is the region of tissue degeneration, which is due to disturbance of hemodynamics of the spiral artery, at the calyx-wall.

The author concludes that, when a factor of renal circulatory disturbance (particularly increasement of capillary blood pressure) joins in such Locus minoris resistentiae, at first hemorrhagic per diapedesin of capillaries is observed and then in the next stage hemorrhagia per rhexin of capillaries occurs, at the calyx-wall.

\section{I 緒 言}

血尿注泌尿器科領域に於いて日常屡々遭遇する重要な 症狀の 1 つであり，その出血源を詳しく檢索するてとに よつて病変部を見出し適当な治療の行われる場合が多 い. 然し種々の泌尿器科的檢查法の発達した今日に於い ても猶扮その原因を解明し得ず，從つて臨床的には唯上
部尿路からの出血という点と, その患側を知るのみで他 に何ら診断的根據定诚及得ない場合, 或いは持続性乃至 間歇性の高度血尿のため腎剔除術を余義なくされる場合 なぞを屢々経驗する．かっる原因不明の腎性血尿に対し 特発性腎出血を命名したのは Nitze と云われているが 1), 文献的にも異論のあるとこらで充分明らかでない。 
前世紀末期頃より次第に進められて来た病理組織学的檢 溹をむとにした種々の名稱，例允ば Senator ${ }^{2}$ の renale Hämophilie, Klemperer ${ }^{3)} \odot$ angioneurotische Nierenblutung, Israel ${ }^{4)} \odot$ chronische hämorrhagische Nephritis, Gottlieb ${ }^{5)}$, Scheele\& Klose ${ }^{6}$ ๑ B1utung aus kleinem Herd 等が擧げられ, 臨床的概念 を更に具体的に示さんとする名稱，例えば志賀》の原 因不明な腎性血尿, Boeminghaus ${ }^{8)} \oslash$ Hämaturie aus noch ungeklärter Ursache, 藤田 ${ }^{9)}$ の原因不明の上部 尿路出血等も見られるが，かように多数の呼糐の存する ことは本症に対する諸家の見解の不一致を示すもので， 今日一般の趨勢はこれらの名稱を 1 括して, 再び Nitże つ所謂特発性腎出血なる表現が廣く用いられる傾向にあ る.

特発性腎出血の病理組織学的研究注古く亦ら数多くの 学者によつて行われ，種々の知見が述べられて来た。 術前に見られた純血性尿が衍後全く消失すると云う事実

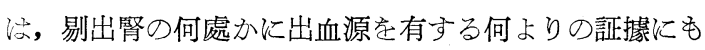
拘らず，今日まで報告された幾多の症例の中には病理組 織学的にも出血源を証明し得ないま>取り残されたもの が可成り見られる。 新井 ${ }^{10)}, \mathrm{Chwalla}{ }^{11)}$ 等々その理由 の1つとして病理組織学的研究が不充分である点を指摘 したが，著者も同様の見解学抱くもので，特腎孟腎杯 壁を同時に含む腎全体の立体的観察が不充分であり，就 中その病態論を論ずるに際し, 腎洞部, 腎杯部附近の血 管構築に関する知識に乏しかつた点は，先覚者をして徒 らに組織所見の解釋を迷わしめる結果を生じをものとも 考え得るところである.

以上の見地から，最初に腎杯部附近の血管構築の在り 方につき檢索し, 次に腎出血の病理組織学的研究に於け る標本作製に際しては Günther ${ }^{12)}$ も指摘した如く, 從 来行われて来た筲長軸に平行割面を入れる切り出し法は 不適当と考え, 後に述べる如き独自な方法を選び, 特発 性腎出血の診断のもとに㹂剔除術の行われた 9 例の剔出 標本の病理組織学的检索を行つた成績につき述べ, 更に 出血の本態に関する私見を記して諸家の御批判を仰ざた 心と思う。

\section{II, 交献的考察}

特発性腎出血については古くから数多くの研究, 報告 を見るところで, その原因論梳複雜多岐であり, 今日に 至るまでの之等の交献主全て收録することは紙面の都合 上困難である. 又最近本邦に於いても岡 ${ }^{13)}$, 原田 ${ }^{14)}$, 仁 平 ${ }^{15)}$ 等により内外の交献からその病因論について詳しく
分類整理した報告がなされているので，こ〉では今日ま での内外交献上, 腎出血に関する諸家の主要研究業績を 歴史的に考察し, 本症病因論関する概要を述べるに止 める.

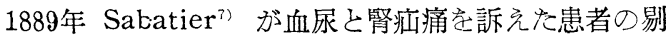
出腎の組織学的检索を行つた結果, 出血の原因を証明し 得ず，乙れ出血性腎痛 Nevralgie hématurique と 呼稱し, Senator 沙血友病の局在性の存在を考え，血 液の変化に加えて，督の血管壁の変化堂伴う場合の 1 現 象と考え腎性血友病 renale Hämophilie そ呼んだ. 又 Klemperer 法斯る症例に対し血管神経性出血説 Angioneurotische Blutung 説を唱え, 血管運動神経の麻痺 が毛細血管の過度伸展をもたらし, その結果毛細血管壁 の破䧑或い怯赤血球の溢出定来すと考えた. Senator も 後にての説导認めているが, 一方 Israel 注剔出腎の 組織学的檢索に於いて限局性腎炎の所見が得られたとて ろから腎炎説を主張し, 腎の詳細な檢索の重要性を强調

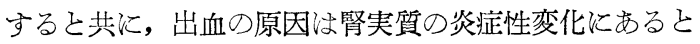
して. Ceelen ${ }^{16)}$ の記載によれば，1902年ドイツ内科 学会汸於いて “ Nierenkolik u. Nierenblutung der Gegenstand einer eingehenden Besprechung”とい う問題を中心として, 当時の最高権威者たる Senator 及び Israel が論争し，組織所見を認めずとする Senator 派に対し Israel 经先に述べた限局性腎炎が出血の原 因で，腎の炎症性充血が腎被膜の緊張をもたらし腎疝痛 の原因となると反駁したとあり，てれらの論争は20世紀 初期に於ける腎出血に対する兩見解を示すものとして, 歴史的意味で興味深いものがある. Israel に前後して 当時腎炎説学支持卞る学者注比較的多く見られ (Kretschmer $^{17)}$, Casper $^{18)}$, Rathbün ${ }^{19 \prime}$ 等), 又当㭙のフラン ス学派の見解については Silva ${ }^{20)}$ の論交に詳しい。 即 ちフランスに於いても出血性腎炎と呼稱せられ，1899年 Albarran, Malherbe \& Lequeu 等は実質の充血を伴 つた硬化性糸球体炎と肥厚性線維被膜炎をとの主な病理 組織学的所見としたが, 出血部についての明らかな記載 を見ない. Pousson \& Desnos（1914）渻割面上に 肉眼的出血巢の存在した例を記載し, 組織学的には糸球 体に赤血球が充滿し，更に Bouman 氏賈内にも証明さ れるところから, 出血性腎炎注血管壁の透過性六進狀態 がその原因と考えた。 以来この説は Marsan (1924), Nicolich (1924), Chevassu (1924), Michon (1925), Langeron \& Bocca (1925) 等によつて支持されて来 たが, Verliac（24）沙実質に限局した腎炎の組織学 
的所見认証明出来るが，乙の変化のみでは臨床上に見ら れる血尿の証明は困難であると述べている.

以来特発性腎出血の研究汭イッ学派の独壇場的観が あり，当時の優れた業績は殆んぞ同國の交献に見られた が、約10年前頃より次第に本症の研究は世界谷國で行わ れる傾向にあり，1958年國際泌尿器科学会に於いても， 此つ問恖が取り舉げられ, 又本邦に於いても近年相次い で各観点からの病態論に関する報告に接する。

双て組織学的裏付を欠く点が其の説の最も難点と考え られた Klemperer 以来の血管神経性出血説流, Junk$\mathrm{er}^{14}$ （1948）の行つた交感神経切断術によつて血尿の消 失を見るとの臨床的裏付を得て, 再び一般の注目を浴び るとこらとなつた。 Frauboes ${ }^{21}$ (1954) は同様の見解に 立脚して硬膜外神経遮断術による腎出血治療の有效性を 説いている. その他自律神経遮断用或い恪冬眠麻醉剂に よ治驗報告例も近年になつて時々散見される. 又 Saare \& Moench $^{22)}$ (1951) 沙クロトン油によるウサギ の腹胿神経䈨刺戟が，腎に lower nephron nephrosis 様变化を生ずることを実驗的に証明し，次いで Griesmann \& Eufinger ${ }^{23)}$ (1952) は動物実驗及び 臨床例 から, 腎出血の原因㳊炎症性のものでなく, 原因の明ら ふな例充ば虫垂炎, 腸閉塞等, 一方原因不明の刺戟が腎 ○血流調節神経系に働き, Druckblutungsstörung 学 来当結果血尿を見るもので，ててに㳊組織学的所見を有 する場合と, 殆んざ所見を欠く場合があると述べ, 組織 学的に証明される Bowman 氏賟内或い泳細管内一 の赤血球游出こ云つた所謂組織学的血尿の集積されたも のが，臨床上見掛ける肉眼的血尿学形成するものであ り, Günther の云う如くErythrurie（組織学的血尿 で腎実質性の出血を意味し, Günther 恃赤血球円柱の 存在を重視している) と Hämaturie (肉眼的血尿で Günther 泳尿路に直接面した部分からの出血と考えて いる）とを敢えて区別して考光る必要はないと述へてい る. それょり以前 Reilly (1934) は植物神経系に直接 物理的或い訛学的侵擎学加えることによつて, その支 配領域のみならず, 遠く離れた谷臟器に種くの非特異性 病変の起るのを認め, 腎に於いてい蛋白尿或い惊時に血 尿を発生せしめ得ることを; 頸靜脈囊法安以つて示し, その事は山口(24)25)26)（1956）によつて廣く本邦にも紹介 された。揇本 ${ }^{27)}$ (1957) は Griesmann \& Eufinger の 行つた各種藥剂による自律神経系刺戟実驗を追試し, 乳 頭に於ける間質性充血像は Reilly 現象に屬する变化で あるこした。 一方 Silva ${ }^{20)}$ (1958), 小川 ${ }^{28)}$ (1959) 沫 Reilly の行つた頸静脈囊法を追試した結果, 臨床的に
特発性腎出血の 1 原因として自律神経障害によるものむ 存在すると推論している.

又独自な報告として Thelen \& Wiegers ${ }^{29)}$ (1954) 汸, 日常尿管内にカテーテルを留置した場合霬丸血尿を 認めるところから，尿管に於けるカテーテルの刺戟が反 射的に腎血流に異常をもたらす結果血尿を惹起するもの と考え, 実驗的にそのここを証明した. この報告の中で 特に興味ある点注, それまでの多くの動物実驗が, 所謂 組織学的血尿の証明に留宗るのに反し, 該実驗では明ら かな血尿を証明したとと，及びその出血源が腎盖粘膜面 に見られたと述べている点を擧げるととが出来る. 又最 近 Heine ${ }^{30)}$ (1953), Finkel ${ }^{31)}$ (1954), 島本 ${ }^{32)}$ (1959) 等は, 臨床上病巣感染性腎出血の存在するととを治療面 より証明している。

Israel 学中心とする腎炎説を主張する1派は，本説 の最も難点と考えられた偏側性腎炎の存在の有無を云つ た問題に対し, 臨床或い注剖檢例から 1 側性腎炎の実存 例を示し (Israel \& Lennander, Pousson, Edebohls, Weiss) ${ }^{6}$, その可能性を主張した。一方 Young ${ }^{33)}(1920)$ 㤃病巢感染による腎炎発生の過程に見られる前腎炎性充 血狀態が腎出血の原因と考えている.

上述の腎炎説に対しては，先に述べた血管神経性出血 説を主張する人从を含めて, 可成り批判的立場を取る学 者が多く,Braasch ${ }^{34)}$ (1913) ほ Broders の擧げた, 腎疾患の既往歴を持たない 320 人の屍体解剖の結果, 200 例 (63\%) 飞腎炎の組織所見学認め，乙れらの人队 以生前全く腎炎の症狀はなく又血尿を認めなかつたと云 う事実を引用し, 腎出血の名棦として腎炎と云う言葉は 不適当であると述べている. 又 Spitzer ${ }^{35)}$ (1914), Günther ${ }^{12)}$ （1944）等核剔出腎の腎炎所見の存在につい ては否定していないが，てれらの所見のみを以つて日常 遭遇する肉眼的血尿の原因と考えるのは誤りで，てれは 飽くまで随伴症狀であり出血源次他に存在するものと考 えた.

双て出血源定腎皿, 督杯, 乳頭部の如き直接尿路江面 する部分に求めんとする傾向㳂可成り古くから見られる ところで, その主なる成因として所謂腎盈逆流現象定逆 に考光た場合及び腎孟, 腎杯, 乳頭部の炎症性变化によ る出血の 2 者学舉げることが出来る. 腎孟靜脈逆流現象 を腎出血の成因の 1 つであるとして最初に記載したのは

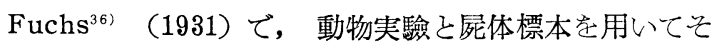
の可能性を示している. Ceelen ${ }^{16)}$ ( 病理組織学的檢索 の結果, 同部附近に於ける腎出血の起る可能性につき 3 
つの場合学擧げ, 解剖学的に見ても腎洞部に於ける靜脈 の位置は腎孟靜脈逆流現象を生じ易く, むしろ該現象発 生の準備狀態を意味するものであると述べている。その 外, 腎孟静脈逆流現象についての動物実驗 $\left(\operatorname{Lewin}^{37}\right.$, $\operatorname{Verliac}^{38)}$, 新井 ${ }^{39}$, 原田・笠井 ${ }^{40)}$ ), 或いは臨床的涪 分切除標本の中に腎盂静脈交通枝を見出したとの報告 $\left(\right.$ Pytel $\left.^{20}\right)$ もあるが, 最近 MacMahon \& Latorra-

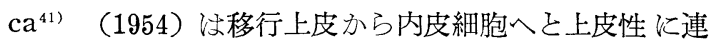
続性定示方腎靜脈交通路学有与腎出血症例 3 例定示し ている. 次いで同部の炎症性変化を以つて出血の原因と 考える学者も多く $\left(\right.$ Ceelen $^{16)}$, Warsch ${ }^{42)}$, Miller \& Yo ung $^{43)}$, Harlin ${ }^{44)}$, Alken \& Hasche-Klünder $\left.{ }^{45}\right)$, そ の代表的人物として Günther ${ }^{46)}$ 47) 48) (1949) を擧げる ことが出来る. 彼は詳細なる病理組織学的檢索の結果, 特発性腎出血己淰即ち出血性腎炎であり, 出血の本態流 腎孟乳頭系の毛細血管性出血である. 又臨床的には無熱 性或いは多くの場合微熱を伴つた腎孟炎, 腎孟乳頭炎, 腎孟腎炎で, 組織学的には殆んぞの場合小円形細胞浸潤 を見るが, 時にはリンパ滤胞様の浸潤学伴い, 同時に組 織の浮腫と硬化像を認めると述へている. それょり以前 飞 Scheele \& Klose 以腎孟の蠕動方進が同部の充血を もたらし, 更に粘膜下組織のリンパ滤胞の存在は屢々出 血の原因となり得ると述へている。一方本邦に抢いても 古くは大野 ${ }^{49)}$ (1930), 岩下 ${ }^{50)}$ (1933) 等の報告を見る が, 最近古沢・大越 ${ }^{51)}$ (1955) 以原因不明の腎出血 3 例 の病理組織学的所見を示し, 本症をすべて 1 元的に解釋 すること注誤りであるが, 腎出血の原因として腎孟腎炎 が少くないととは臨床家の銘記すべき事項であろうと述 べ, 巾 ${ }^{52)}$ (1958) も10例の組織所見から同様の見解を示 している.

次㵊近 $\operatorname{Martin}^{53)}$ (1951), Heine ${ }^{30)}$ (1951), Nat1$\mathrm{on}^{54)}$ (1952) 等は本症の原因にアレルギー性因子の関 與する事を指摘し, Nation 汸その組織学的特徴として 腎孟粘膜下出血と, リンパ球及び好酸球の細胞浸潤が見 られると述べている。

又腎出血の原因の1つとして腎の燹血狀態を重視する 学者も可成り多く, Payne \& Mac. Nieder ${ }^{55)}$ (1916) 以皮髓境界部の瘢痕形成による静脈流の阻止狀態が乳頭

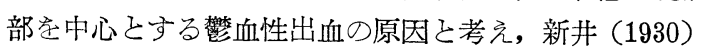
涩更に動物実驗を加えて略々同様の見解を示し, 慢性腎

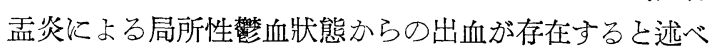
ている. 又魏血の原因を腎外性因子, 即与異常血管や 腎の位置異常に求めんとする人もあり, 清水注立位腎孟
撮影 ${ }^{56)}$ 或いは立位大動脈撮影 ${ }^{57)}$ の意義を強調し, 又岡

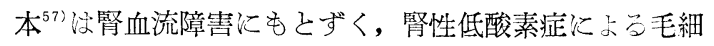
管透過性充進狀態を重視している.

最後に特異な症例として Bogliolo \& Silva ${ }^{59)}$ (1954) の記載した, Juxtaglomerular Apparatus (Polkissen）の著明な肥大と増加を認めた腎出血例を學げ得る. 彼等当当時これらの細胞の肥大及び増殖の意義について は詳述を避けているが, Polkissen について流既に Oberling $^{60)}$ (1944), Zimmermann ${ }^{61)}$ (1933), Becher ${ }^{62)}$ （1937）等は腎内血流量調節を司るものと考えて扮り, 更飞後述する Polkissen の発達々腎直達血管の発達が 系統発生学的に見て対蹠的関係を有する点が明らかとな つた今日, 兩者の何れかの異常な増殖肥大による機能九 進狀態が腎内血流量に異常をもたらし, 腎出血の原因と なつたものとも考元られる点で極めて興味深く特に附記 した.

\section{III. 基礎実験}

吾々が或る臟器の生理並びに病理を解明せんとする場 合, 基礎的事項としてその臟器に於ける血管構築の在り 方関する解剖学的知識を必要とするととは云うまでも ない. 況して特発性腎出血の如く出血を対象とする疾患 に於いて, この問題が比較的等閑斍されて来た事実以む 乙ろ奇異の感すら懐かせる. 腎内血管系の解剖生理学的 事項に関しては今日までに朁に幾多の業績があり, 成書 とも廣く記載を見るところである. 又腎孟腎杯部の尿排 泄路としての解剖生理学的研究も, 辻 ${ }^{63)}$, Narath $^{64)}$ ごの優れた業績を見るが，腎杯部附近の血管系汇関卞る 檢索流, 該部が解剖学的にも比較的入手困難な点などか ら，今日まで殆んで無峴されて来たて云つても過言でな い. 斯る現狀に鑑み, 著者洔発性腎出血症例》病理組

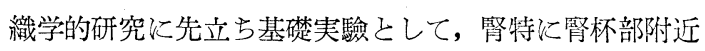
の血管構築について観察した.

a) 実驗材料及び実驗方法

i ) 使用材料

主剤: Methylmetaacrylate

触媒: Benzoyl peroxide

可塑剤 : Dibuthyl phthalate

重合促進哓: Dimethylaniline

ii）調製法. 注入液作製々あたつて以，江口 ${ }^{53 j}$ の方 法に略々準じたが, 中間重合体の粘䅕度その他の細部の 点については本学第 3 解剖学敉室松田助敋授の指導老仰 いだ. 即ち主鼡に触媒を $1-2 \%$ の割に混じ, $80^{\circ} \mathrm{C} \pm 2$ ${ }^{\circ} \mathrm{C}, 30$ 分間恒温裝置の中で䚓汼し, 適度の粘稠度の中間 
合体を作つて冷暗所に保存する。使用前に上記中間重 公体 100 亿対乙触媒 0.5 , 可塑郕 20 , 重合促進郕 1 学混 ざる.

iii）被驗材料 婜結石症例 2 例，初期腎結核症例 1 例, 計 3 例の剔出筒を用い宗.

iv） 注入法 上記混合液法時間の経過と共に重合硬 化する故速吢に注入完了しなければならない. 剔出腎 の腎動脈流その後の操作を容易ならしめるために充分剝 離し, 注入液沙注射器に入れ特殊なカニニーレを以つて

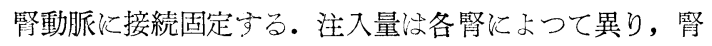
の疗変部の大小によつても左右されるが, 著者纺注入し た液により腎が適当なる膨みこ硬さを得，更に腎被膜に 存在する血管系走通して注入液が漏出し始める時期毒以 つて注入完了と見做した。

注入完了した腎々 $60^{\circ} \mathrm{C}-70^{\circ} \mathrm{C}$ 亿約 1 時間加温して合成 樹脂の重合硬化方るの老待与, その後流 $20 \% \mathrm{NaOH}$ 液 に $1-2$ 書夜浸漬して組織成分学腐蝕させ，更に流水中 で腐蝕し組織を完全に洗い落し乾燥した。

b）実驗成績（等杯部血管構築について）

以上述べた合成樹脂注入法で得た腎動脈鋳型核圖（第 1，2 圖寥照）飞示す通りで, 腎動脈心ら直ちに 2 本の 太い血管即与葉間動脈江分礼，更に弓狀動脈，小葉間動 脈と分枝し，その末梢部に於いて糸球体注㯨粒大の小䊉 子となつて無数に附着している. 梷杯部附近に到る血管 は葉間動脈或い法時に弓狀動脈尗ら約 $90^{\circ} \mathrm{C} の$ 角度を持つ てふ枝し，特異な螺旋狀走行を示しつ〉腎杯部附近に集 つている．更に細部宅擴大して見ると，本血管系淰末 梢部に近ずくに從つて螺旋狀形態が著明となる傾向定示 し，比較的分枝に乏しい. 同血管の直経は $100-200 \mu$ で, 最も強く螺旋狀形態示すのは $100 \mu$ 前後の直徑定 有する部である。

c）考察（螺旋動脈について）

粲杯部附近にこの様な血管系の存在する事を最初に記 載したのは Spanner ${ }^{66)}$ (1939) で，腎に於ける動静脈 吻合関する研究の一端として, 腎洞部血管系の特異性 につき述へている．然しその後多くの研究者の注目を惹 くに至らず，近年 Trueta et al. ${ }^{65)}$ (1947) は再び該部 の動靜脈吻合に関する問題を取り舉げ論じている. 江口 （1958）は合成樹脂注入法で得たヒト腎の動脈鋳型を詳 細に檢索し, 糸球体を介さない血管系即与腎直達血管 4 種 (1. Circulatio directa parenchymatis renum: 糸 球体を介在しない腎実質内直達血管. 2: Circulatio directa capsulae renum: 腎被膜に到る直達血行路. 3,
Circulatio dir ecta tunicae mucosae pelvis: 腎㙉 腎杯壁に分布する直達血行路. 4. Circulatio vasorum vasorum：腎内の大きい血管壁の栄養血管系））を舉 げ, その中腎孟腎杯部へ到る螺旋狀走行を示す血管系に

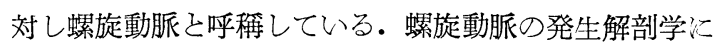
関しては系統発生学的方面からは江口の業績があり, 又 個体発生学的には Baker ${ }^{67)}$ (1959) の夫れを見るが, 要するに本血管系泣各動物の種屬によつて之を有するも のと殆んで有しないものがあり，その関係腎皮質に於 ける所謂 Polkissen の数々略从対蹠的関係が認めら れ，このととは腎直達血管系が腎血流調節作用学有する 極めて有力な亭付である (江口).又本血管は 4 才以下の 小兒期に於いて治んで発見されず，真直か僅かに軽度 のねじれを示すに過ぎないと云われている。（Baker） 螺旋動脈の更に末梢部は筲杯粘膜下層或いは筋層に於心 て毛細血管網を形成し, その形態を江口注蓮の荎と葉脈 との関係に譬えている.

螺旋動脈の機能については今日まで定説は無く, 又女 まり詳しい記載导見ない。江口は腎杯部の栄養と腎血流 量調節作用を有すると述べ, Spanner, Trueta et al. も略々同様の見解で，特に同部の動靜脈吻合を重視して いる. Baker は本血管の末梢部は更に腎乳頭部に到り 該部血管系即与 vasa recta と吻合し, 腎乳頭部の栄盖 を司ると述べたが，著者の行つた腎動脈合成樹脂注入法 によつて得た標本ではその様な吻合部は証明し得なかつ た.

螺旋狀形態を示す血管系は，腎杯部に限らず身体の種 ふの部に見られるもので，例えばその代表的なものとし て子宮壁, 卵巢, 肺などを舉げることが出来る.子宮壁 に於ける螺旋動脈々同部に見られる動靜脈吻合が内分泌 的影響のもとに月経を形成するとの説は既に成書にも記

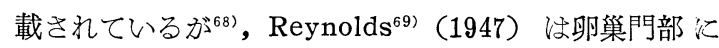
見られる螺旋動脈は血中に流れて来たホルモンを卵巢組 織全体に平等に分配すべく 1 種の血流調節作用を有し, 更に妊娠こ云了特殊な狀態に適應するための形態である と考元ている. Tobin ${ }^{70)}$ (1952) 以又血流調節作用を有 する螺旋動脈导肺胞と気管支の循環系の吻合枝として記 載している.

以上是等の螺旋動脈沙全て何等かの形で血流調節作用 を司つているとと， 又江口の云うところの Polkissen と本血管系の因果関係, 更に腎杯部に分布する直線的走 行定有する血管系に較べ本血管の直俓が著しく大である こと（江口，Baker）などを考え併せる時, 腎杯部螺旋 
動脈が腎血流調節作用上極めて重要な血管系であると阔 時にその反面では，從来考えられて来た腎に於ける他の 血管系に較べ, 腎杯部螺旋動脈淰常に腎血流量調節々云 引大きな負擔学負わされた特殊な血管系と考元るととも 出来る。

\section{IV. 研究材料及び研究方法}

\section{i) 研究材料}

肉眼的血尿を主訴とし，臨床的に腎出血の原因を解明 し得ず, 種々の保存的療法に抵抗性守した岛, 止むな く腎剔除術を施行した 9 例の剔出腎について檢菜した.

2）研究方法

剔出腎注最初に腎凸面より正中割面を入れ，腎実質及 び腎孟面に於ける肉眼的变化の有無につき检索を行い, これを 2 分して一方は10\%ホルマリン固定, 他方をアル コール固定を行い, 特殊染色時の便宜を圖つた. 固定後 正中割面上に見られる腎乳頭及び割面上に現われていな 心乳頭部を含め, 肉眼的所見の有無に関係なく, 剔出腎 に於ける全乳頭部に対し正中割面に垂直の方向に約 5 $\mathrm{mm}$ 間隔で腎盂腎杯及び䯕質皮質の全てを含さべく切開学 加えた。從つて 各乳頭部につき $2-4$ 個の組織片学作 り,乙の組織片につき可及的連続切片を作製した（第 3 圖公照).

染色法こしては Hematoxylin-Eosin 重染色, Masson 氏 Trichrome 染色並び同染色 Goldner 氏変法, Gomori 氏鍍銀法飞よる格子線維染色, Weigert 氏彈 力線維染色, PAS 染色, 組織内細菌染色 Goodpasture
法（マツカラム変法）を行つた.

\section{V. 自験例の臨床的並びに病理組織学的所見}

次䏡示 9 症例法今日一般行われている泌尿器科的 檢查及び一般臨床檢查に於いて特記すべき所見を有しな いものであり，茲で㳉その檢查成績の詳細柱省略し，特 に重要と考えられた所見の及岂記すことにする。從つて 腎機能檢査は総腎機能に異常を認めなかつたので, 分擔 腎機能としてのインヂゴカルミン試驗成績のみを記し， 又腎盂形態は病変部 1 覽表に Schema を以つて示した (第 1 表).

〔症 例】

第 1 例. 山○某, 27 才。. 初診 : 昭和 32 年 6 月 1 日. 既往歴及び家族歴 : 昭和 30 年 4 月胃蛽癔及びアルコー ル中毒で内科的治療老約半年間受けている.

現病歴：昭和 31 年 7 月㔖然血尿に気付き約 1 週間で自 然治癒を見た．その後も特別誘因なく $4-5$ 日間続く血 尿を認め, 最近肩凝り, 贏瘦を訴元来院した。

現症：兩側腎共飞触知不能．尿注血性溷濁尿で，洗渣 法赤血球 $(\#)$,白血球 $( \pm)$,細菌 $(-)$.膀胱鏡檢查 : 膀 胱粘膜異常なく，左尿管口ょり血性尿の排出が認められ る.インヂゴカルミン試驗：左右共 2 分50秒で初染し, 3 分 45 秒で濃青となる。

治療 : 約 2 力月間種々の保存的療法字試みたが效果 認めず，昭和 32 年 8 月 12 日左腎剔除䢙を行つた.

経過: 琎後血尿注全く消失し, 昭和 32 年 9 月 2 日退 院，以後再発を見ない。

第 1 表 病変部一覧表

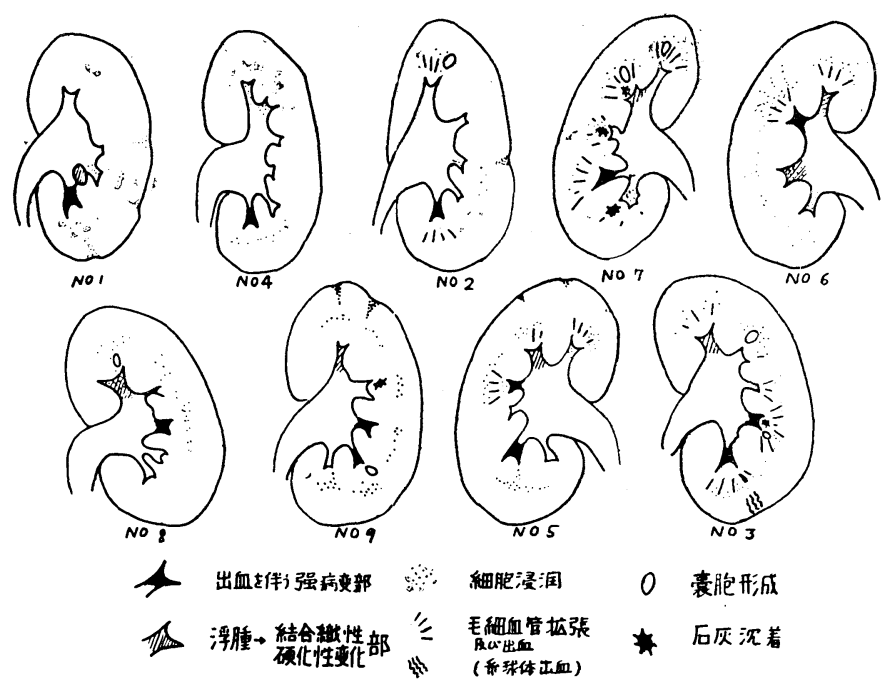


剔出腎肉眼的所見：大きさ $9.5 \times 5.5 \times 3.5(\mathrm{~cm})$ ，

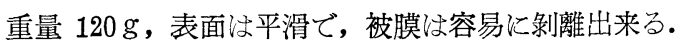
割面では腎実質に異常所見なく, 腎盂粘膜は下腎杯部附 近に点狀出血斑を認める以外異常所見はない.

病理組織学的所見

腎盐腎杯部: 粘膜上皮は略々正常で 1 部に軽度の増殖 性変化, 上皮層内に赤血球及び少数の白血球の介入学認 める. 主要病変部牥粘膜下固有層, 筋層, 脂肪組織に見 られ，腎杯壁全般に亘つて小円形細胞を主体とする高度 の細胞浸潤，毛細血管擴張及び部分的な浮腫が見られ， 出血は粘膜固有層及び粘膜外層何れにも認められるが, 粘膜固有層の出血认特に著明で, 細胞浸潤部に涺慢性に 拱がる部分と，一方限局性で粘膜基底層を底邊とする逆 三角形の小血腫を形成する部分も存在する. 更に出血巢 を詳細に観察すると, 出血部に一致して筋層㹥断裂傾向 を示し, 粘膜固有層, 外層, 脂肪層も本来の配列形態を 失い, 線維素の析出, リンパ球, 組織球, 線維芽細胞を 思わしめる核小体の明膫な大型の紡錘形細胞の出現, 更 に好酸球も散見出来る. 又該部他他較ベエオジン好染 性傾向を示した (第 4 圖).

同病変部に於ける螺旋動脈の態度学観ると, 血管壁全 体が著しく肥厚膨化すると共に，血管内皮細胞を除いて 他の細胞治殆んど消失している.（第 5 圖).更にこの血 管壁変性を連続的に追跡すると, 腎洞部脂肪織内に集束 的に存在する同血管の中, 明ら加同様の血管壁变性を 伴うもの学区別出来る. 斯る集束的に存在する部に於い て, 全〉健康と思われる血管と変性を伴つた血管の内腔 定比較すると，前者に於いては少数の赤血球を有する か, 時に注むしろ充血性態度を示すのに反し, 後者に於 ける血管埶活狭小となり, 殆んぞの場合血球成分を欠除 している.

以上の変化は下腎杯のみ限局して存在し，その他の腎 杯或いは腎盎に於いては殆んざ著变定認めず, 軽度の浮 腫或い结結合織増生学見るのみで, 出血巢注証明出来な い.

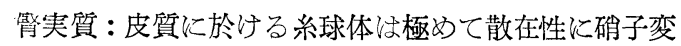
性が認められ, 又皮質邊縁部に近く限局性楔狀の小円形 細胞浸潤と腎被膜の肥厚を伴つている部もある（第 6 圖).主部尿細管は 1 部腫脹し管腔の狭小化を認める部む 㟧るが軽微である. 皮質血管系忹全般的に軽度の内膜肥 厚傾向及び血管周囲性小円形細胞浸潤が認められた。

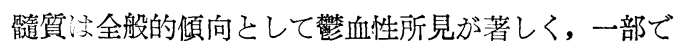
は毛細血管の破綻像を証明出来るが, 出血に伴了組織反
應は顯著でない。集合管内腔は時に硝子様円柱を認める が, 赤血球核証明出来ない。

乳頭部は軽度の間質増殖, 毛細血管擴張, 部分的浮腫 像を認める。

組織内細菌染色により病原菌は証明出来ない。

第 2 例. 猪 $\bigcirc$ 某, 33 才。. 初診: 昭和 31 年 1 月 31 日. 既往歴及び家族歴：特記すべきことはない。

現病歴：14年前特発性腎出血の診断のも己に約20日間 保存的療法を受け軽快した経歴を有する。今包的 8 力 月前から血尿を認め体動飞より増強する傾向があり，同 時飞最近内科医により貧血を指摘されて来院した。

現症: 頚血が認められるが, 病的血球成分或いは出血 性素因泣証明されない. 兩側腎共飞触知不能. 尿注純血 性で溷濁し, 沈椬浾血球 (卅), 白血球 $( \pm)$, 細菌 (一). 膀胱鏡检查 : 膀胱粘膜注正常で, 左尿管口ょり血尿の排 出認め, 膀胱底部拇指頭大の凝血が存在する.イン ヂゴカルミン試驗以高度の血尿のため判定不能である。 総腎機能注正常で, 排泄性腎孟撮影による左右腎の機能 も正常である.

治療 : 入院後 1 力月間, 輪血, 止血滆投與その他の保 存的療法を試みたが効果を認めず，昭和 31 年 3 月 14 日左 腎剔除術を行つた。

経過：䢖後血尿决消失し，昭和 33 年 4 月 4 日退院し以 後再発を見ない.

\section{剔出腎肉眼的所見}

大きさ $11.5 \times 5.8 \times 4.2(\mathrm{~cm})$, 重量 $135 \mathrm{~g}$, 表面平 滑, 被膜法容易飞剝離出来る. 割面注於いて腎実質は上

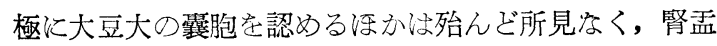
面は下腎杯に小凝血を認めるが，粘膜面に異常所見を認 めない。

病理組織学的所見

腎孟腎杯部：全般的に粘膜上皮の退行性変化が著明で ある、腎杯壁の変化㹥下腎杯に於いて特に著しく, 腎杯 窎蕯部に近い粘膜下層注本来の組織構造が殆んぞ消失し エオジンに淡く均等性に染る限局性瘢痕形成像を認め る. この部の周囲存在する毛細血管は強い擴張傾向走 示し，一部では赤血球の漏出を伴つている. 又限局性 瘷痕部々周困結合織との間に注裂隙が見られ，恰も同瘢

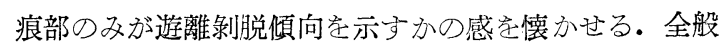
的に見て細胞浸潤屾軽度である (第 7 圖).又該部に至る 螺旋動脈注粘膜外層に於いて血管壁の肥厚硬化性变化が 著しい(第 8 圖).

督実質 : 皮質に於ける血管系は軽度の内膜肥厚傾向が 
認められ，糸球体の硬化像を散見する。髓質は全般的に 毛細血管の擴張或いは破緃像が認められ, 乳頭部に於い ては結合織の増殖傾向が著しく, 上極の乳頭部にムチン 椂物質を充した賈胞を 1 コ認めたが, 同囊胞の周囲組織 は比較的所見にそしく, 集合管の圧排像のみで出血巢は 証明されない。

腎錐体の周囲結合織即ち Bertin 氏腎柱内を走る葉間 動脈から分枝したと考えられる 2 本の螺旋動脈の中, 一 方は全く健康と思われるもので，1列に断続的な配列定 示し, 血管壁には紡鍾形乃至注棈円形の核が比較的整然 と並び, 内腔血液要素で充されているのに反し, 他方 の螺旋動脈は血管壁細胞は殆んぞ消失し, 結合織線維は 膨化を伴い, 從つて血管壁全体が無構造化し, 内腔決狭 小で血球成分は久除している. 更に Masson 氏 Trich rome 染色では, 健康な血管壁が紫色即ち可成り筋性要 素を有するのに対し, 変性を伴つた血管壁はアニリン青 による青色色調を示し, 所謂結合織線維の增殖が認めら れる. Goldner 氏変法による場合はライトグリーンに よる淡緑色色調を示した. 更に Gomori 氏鍍銀法でも 兩者は明らかな差異を示し, 健康血管壁に流色に染つ た微細な線維網を認めるのに反し, 变性血管壁には同線 維網定欠き淡褐色色調を示す線維群のみが認められる (第 9 圖).

一般的な傾向として螺旋動脈は彈力線維にそしく, 健 康な血管壁に於いても纎細な彈力線維が内膜及び中膜に. 極めて粗に存在するが, 変性血管壁では殆んごの場合同 線維の消失を認める (第10圖).

組織内細菌染色で病原菌は証明されない。

[小 括]

以上 2 症例の中, 第 1 例は肉眼的檢索に於いて㭚に下 督杯に粘膜下出血斑を認め, 病理組織学的にもその部に 一致する出血巢を認めたが，第 2 例に於いては腎凸面か らの正中割面上では粘膜面及び腎実質に異常所見を認め ず，割面上に現われていない腎杯角に於いて，組織学的 に病変部它証明出来た。兩例共病理組織学的に特異な所 見を有する腎杯は 1 コの久で, 他の腎杯次比較的病的所 見にそしかつた。即与第 1 例では腎杯壁全層に亘る出血 之初期肉芽形成像が見られ，一方第 2 例恃限局性の痗痕 形成像己周囲結合織内の出血を伴つた毛細血管の擴張像 がその主要所見であるが，今兩者の組織像を比較した場 合, 兩者の閏には出血 $\rightarrow$ 肉芽形成 $\rightarrow$ 結合織增殖硬化 $\rightarrow$ 限 局性痽痕形成こ 1 連の関連性定窥うことも出来る. 同時 に兩症例の病変部更に脂肪織或いは Bertin 氏腎柱結合
織内に見られた，硬化性変性を伴つた螺旋動脈の存在す る点も注目すべき所見と考える.

又兩例共髓質に於ける豨血性变化が著しく, 特に第 2 例では該部毛細血管壁が破綻し, 間質内に小出血巣が点 在するを認めた。

第 3 例. 野○某, 31才。, 初診 : 昭和33年 9 月 10 日. 既往歴及び家族歴: 21 才のとき肋膜炎, 現在胃下垂症

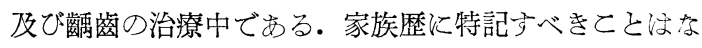
w.

現病歷：約 1 週間前より血尿を認めたが， 3 日前頃か ら尿中に凝血を混じ, 同時に排尿障害を認めて来院した.

現症: 兩側腎共に触知不能. 尿仗肉汗色溷濁尿で凝血 を混ずる. 沈椬は赤血球 (卅), 白血球 $(+)$, 上皮 $( \pm)$, 細菌としてグラム陰性小桿菌を極く少数認める. 膀胱鏡 檢查: 膀胱粘膜洛々正常, 左尿管口ょり血尿の排出定 見る.インヂゴカルミン試驗: 右 4 分 10 秒で初染し, 5 分 30 秒で濃青となる. 左注血性尿高度のため判定不能で ある.

治療 : 保存的療法に抵抗し, 出血高度のた少昭和 33 年 9 月26日左腎剔除術を行つた.

経過: 術後血尿は消失し, 昭和33年10月10日退院し, 以後再発を見ない.

剔出腎肉眼的所見

大きさ $12.5 \times 5.6 \times 4.2(\mathrm{~cm})$, 重量 $165 \mathrm{~g}$, 表面织平 滑で被膜穴容易に剝離出来る. 割面では軽度の腫脹と髓

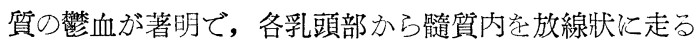
血管系を明視出来る. 又上極髓質内に小豆大の䟲胞 1 個 を認める. 腎盂粘膜面牥殆んご異常所見を認めない。

病理組織学的所見

腎盂腎杯部：腎杯粘膜上皮々増殖性变化小認めない

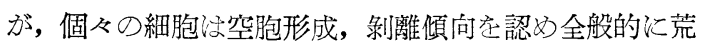
廃した感じを有する。粘膜固有層淰結合織性増殖著明 で, 筋線維は萎縮性のため固有層との境界が判然としな い. 同部の螺旋動脈注血管壁の硬化性変化が著しく, 該 変性血管の存在する腎杯壁は全体的に萎縮菲薄化したか の感定呈し, 小円形細胞を認めるが軽度である. 糆杯角 に近く, 粘膜固有層に限局性の浮腫及び毛細血管擴張像 が見られ, 同時に赤血球浸潤を伴つている. 又高度の変 性を示す螺旋動脈壁と周囲結合織との組織間隍にも出血 䉓を認め, 更に層狀に擴大傾向を示す (第11, 12圖).

以上出血性病变部字伴つた腎杯法腎下極に於汀る 2 腎 杯に限局し, 他の腎杯では固有層の浮腫或い洁合織増 
生傾向を伴うか, 全く病的所見を有しない腎杯も存在す る.

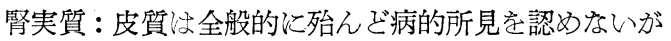
下極に於いて督外表面に近く限局性の実質内出血を認め る. 即ち出血巢浨糸球体を中心としたもので, Bowman

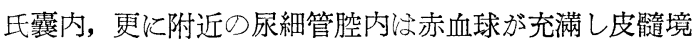
界部附近ふで追跡される. 出血巢はへモジデリン沈着を 伴い, 周囲尿細管上皮は軽度の腫脹傾向を示すが細胞浸 潤ふ顯著でない(第13圖).

皮䯣境界部に於ける弓狀動靜脈周囲結合織埌小円形細 胞浸潤已結合織増殖傾向を認める.

髓質况菘血性変化が著しく, 毛細血管の破綻像が点在 する.出血巢の周囲組織は特異な变化を認めないが, 一 部の赤血球ほ更に集合管内腔に流入している. 乳頭部に 於ける間質は部分的な 浮腫或い注結合織の増殖が著明 で, 該部毛細血管は蛇行傾向を示し, 部分的な擴張或い は狭小部が見られる.同様の変化は集合管にも見られ， 同時に囊胞形成安認める部も存在する (第14圖).一方乳 頭尖に近く, 出血を伴つた石灰板剝離像（第15圖）导認 め, 又乳頭上皮淰退行性変化定伴い一部で剝離㖽向走示 寸部も存在与る。

特異所見として，上極䴛杯角に極めて近接して可成り 太心静脈（篎葉間静脈）が位置し，腎杯角汇証明される 小円形細胞浸潤が, 更に連続性に該靜脈壁に周囲に波及

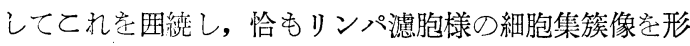
成している・靜脈壁は一部に著しく肥厚を示す部位があ り，更に一部では血管壁結合織線維浮腫狀に膨化し， 層狀離断像が見られる. 連続切片に於いて血管壁周囲の 細胞浸潤己督杯角部の夫れは互いに連続的に証明出来る が，血管壁の破綻像はなく，從つて静脈内腔乞腎杯内腔 の交通路以証明出来ない (第16圖).

組織内細菌染色により同部に病原菌以証明出来ず, 刃 その他の部に於いても細菌は陰性である。

第 4 例. 笠○某, 32 才 + , 初診日 : 昭和 34 年 1 月 30 日.

既往歷及び家族歴：特記すべき事はない。

現病歴：4 力月前より肉眼的血尿を認め, 体動により 増強する.その他の自覚症は認めない.

現症：患側腎沙触れず圧痛を認めない，尿は血性溷濁 尿で, 沈洫は赤血球 (卅), 白血球 $(+)$, 上皮 $( \pm)$, 細菌 としてグラム陰性小桿菌少数を認める. 膀胱鏡检查 : 膀 胱粘膜正常, 左尿管口ょり血尿の排出を認める.インヂ ゴカルミン試驗：左 4 分 32 秒で最初から濃青, 右 5 分 42
秒で初染し 7 分で濃青となる.

治療: 尿感染の消失後も猶礽血尿の持続安認め, 昭和 34 年 2 月20日左腎剔除術定行つた.

経過 : 順調に経過し, 術後今日まで 1 度も血尿を見な い.

\section{剔出腎肉眼的所見}

大きさ $11.5 \times 4.5 \times 3.1(\mathrm{~cm})$, 重量 $125 \mathrm{~g}$, 表面は平 滑, 被膜仗稍々肥厚性であるが剥離は容易である. 上極 より可成り太い異常血管が入つている. 割面上腎実質に 著変を認めず，腎孟粘膜に散在性の小出血斑が見られ， た.

病理組織学的所見

腎孟腎杯部: 粘膜上皮に著しい増殖性变化が見られ, 一部で沙䋐毛様つ増殖を認める. 粘膜下固有層淰小円形 細胞の浸潤学認め, その主体安なすものは血管周围性の リンパ球浸潤であるが, 時に好酸球, 形質細胞も見られ る. 又細胞浸潤は粘膜直下に於いてリンパ球集簇巢を形 成している部分もある. 全般的に毛細血管の擴張傾向が 著明で, 更に下腎杯に於いて泣粘膜下固有層, 筋層字中 心とする出血巢分証明され，同時に粘膜直下に於いても 散在性の小出血巢が認められる。出血巢注へモジデリン 沈着, 小円形細胞, 好酸球, 組織球等の浸潤寽伴つてい る(第17圖).

腎実質：下極腎皮質に於いて血管周囲性小円形細胞浸 潤が著しく，上極に存在した異常血管の周囲組織に新鮮 な出血巢が見られたが, 糸球体及び尿細管には特異所見 を認めない. 髓質毛細血管系は中度度の擴張傾向を見る が，腎杯部に較べる己軽度である。乳頭部間質内には旅 慢性の小円形細胞浸潤を認める. 腎洞部脂肪織内に硬化 性変化を伴つた螺旋動脈を証明出来るが，筒杯壁に至る 走行については不明で, 唯同变性を示す螺旋動脈が出血 巢を有する腎杯粘膜下外層に証明出来た.

組織内細菌染色で病原菌は証明出来ない。

[小 括]

以上 2 症例は臨床的に或る時期に於いては尿中細菌を 証明された既往歴を有する点から別個に取扱つた。 病理 組織学的に証明される腎孟炎の所見に関する問題注後述 するが, その外兩症例に於ける特徴的所見こして㷩血性 変化を擧げ得る. 邡るる所見字す部位としては腎杯 壁, 髓質特に皮髓境界部附近, 乳頭尖を擧げることが出 来る. 㷊血の原因こして第 3 例では腎杯角に近接して存 在する腎葉間靜脈壁に証明された慢性増殖性靜脈炎を指 摘出来る. 第 4 例に於いては異常血管による腎血流障害 
が一應疑えるが確証は掝及得ない。

第 5 例. 上○某, 34 才令, 初診: 昭和 33 年 1 月 14 日. 既往歴及び家族歷：特記すべきことはない。

現病歴: 約 8 力月前より肉眼的血尿を認め, 種々の止 血郕投與による治療安受くるも軽快せず来院した。

現症: 兩側腎共触知不能. 尿注血性溷濁尿で, 沈渣は 赤血球 $(\mathrm{W})$, 白血球 $( \pm)$, 上皮 $(-)$, 細菌 $(-)$. 膀胱鏡 檢查 : 膀胱粘膜正常. 左尿管口ょり血尿の排出を 認め る. 自律神経機能檢查 : アドレナリン試驗 (卅),ピロカ ルピン試驗 (卅),アトロピン試驗 (W).

治療：種々の保存的療法を試みたが効果を認めず，昭 和33年 1 月 31 日左腎剔除術を行つた.

経過: 術後血尿淰消失し, 昭和 33 年 2 月 26 日退院し以 後再発を見ない。

剔出腎肉眼的所見

大きさ $13.0 \times 5.0 \times 3.5(\mathrm{~cm})$, 重量 $130 \mathrm{~g}$, 表面は平 滑で被膜は容易に剝離出来る.割面は腎実質全体が暗赤 色色調が強く，一見して血液成分の多い感圭與える. 腎 孟粘膜面に点狀出血斑が散在する。

病理組織学的所見

腎孟腎杯部: 粘膜上皮汸増殖性变化を認內ないが, 架 胞变性が著明で細胞配列が不規則となり, 又上皮剝離傾 向が著しい. 粘膜固有層は血管周囲性小円形細胞浸潤が 認められ，全般的に浮腫が著明である. 該部の毛細血管

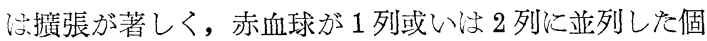
々の毛細血管を粘膜上皮直下まで追跡出来る. 處々に漏 出性出血が見られ，乙れ被膜下出血巣を形成してい る.螺旋動脈注處により充血傾向学認める (第18圖).一 方腎杯角に近い部位で螺旋動脈流高度の硬化性变化が認 められ，元の分布領域に一致して筋層は萎縮退化傾向它 示し, 結合織線維の増殖が著明なため腎杯壁全体として 注硬化性変性像を呈する．更に腎杯角に於いては硬化し た腎杯壁に亀裂面が見られ, その組織間隙に強い出血巣 が証明出来る. 出血巢法更に粘膜下層へ擴大し, 粘膜上 皮直下まで連続している(第19圖).

腎実質：実質全般に充血傾向が著しく，糸球体内赤血 球も増加の傾向を認めるが炎症性変化はなく, Bowman 氏囊内に赤血球は存在しない。髓質及び乳頭部に於ける 毛細血管系证著明な撗張を示し一部に破綻像を証明出来 るが, 周囲の組織反應は顯著でない。

腎洞部に於ける太い血管系には異常所見を認めない が，同部脂肪織内に存在する螺旋動脈と隣接した静脈と を比較した場合, 腎杯外膜で得た所見々異り整血性变化 が著明である(第20圖).
[小括]

本例は臨床的に自律神経緊張症を合併する点で特異な 症例と考光る. 其の事は剔出㱟の肉眼的所見に於いて, 更に組織学的にも毛細血管系の搌張という形に於いて特

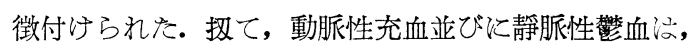
末梢に於ける毛細血管圧六進という点では, 同一視出来 るむのであり，本例は毛細血管圧方進狀態が腎出血に於 ける出血機轉の重要な 1 因子となる可能性を示す貴重な 症例と云い得る. 出血の型としては所謂毛細血管漏出性 及び破綻性出血が見られた。

第 6 例. 中○某, 54 才里. 初診: 昭和 33 年 6 月 2 日. 既往歴及び家族歴：特記すべきものはない。

現病歴: 約 2 力月前上り血尿学認め, その他の自覚症 狀はない。

現症：患側腎は触れず圧痛も認めない。尿は赤褐色溷 濁尿で, 沈渣浾血球 (卅), 白血球 (十), 上皮 (一), 細 菌 (一). 膀胱鏡檢查 : 膀胱粘膜正常, 左尿管口ょり血尿 が勢よく噴出するのを見る.インヂゴカルミン試驗：左 右共 3 分 35 秒で初染し, 4 分 30 秒で濃青となる.

治療 : 種从の療法に抵抗性定示したため, 昭和 33 年 6 月18日左腎剔除術定行つた.

経過: 術後血尿统全〉消失し, 昭和 33 年 7 月 3 日全治 退院した. 再発憀めない。

別出腎肉眼的所見

大きさ $11.5 \times 4.8 \times 3.4(\mathrm{~cm})$, 重量 $120 \mathrm{~g}$. 表面は平

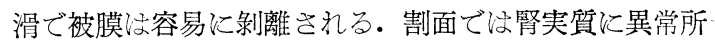
見を認めず，腎孟粘膜に点狀出血斑が散在する.

病理組織学的所見

腎盂腎杯部 : 粘膜上皮は全般的に正常な部分がその大 部分を占內, 軽度の空胞变性を伴了細胞, 或い汸移行上 皮の剝離部を散見する. 組織内細菌染色により該剝離上 皮細胞内にグラム陰性の短程菌群を証明出来た（第21 圖).粘膜下層は出血巢の有無とは殆んぞ無関係に, 各腎 杯壁の結合織性増生及び浮腫傾向が認められ, 筋層は殆 んぞ消失し, 腎杯壁全体が萎縮硬化傾向を示す. 即与斯 る部位に於いては, Masson 氏 Trichrome染色により 青色色調を示し, 又 Gomori 氏鍍銀染色で淡黄褐色を 呈する所謂翏原線維がその主体をなし, 硬化性変化を示 す螺旋動脈の外膜を形成する結合織線維との判別が困難 である(第22圖).出血巢は腎杯角並びに腎杯粘膜下組織 に見られる. 即与硬化性結合織增生を伴つた腎杯角の亀 裂部の組織間隙汇証明される出血巢法, 更に腎杯角粘膜 上皮の欠損部から腎杯腔内一と続いている(第23圖).又 
粘膜下組織の毛細血管の擴張と 漏出性出血像も証明さ 孔, 周囲結合織の浮腫, 小円形細胞浸潤を伴っている (第24圖，第25圖).

腎実質 : 実質内血管系法全般的に内膜肥厚傾问学しめ し, 小円形細胞浸潤を伴い, 又糸球体の硝子変性も散見 される。尿細管ば特記ずべき所見学認めない。一方髓質 に於いて性間質結合織の増殖, 毛細血管系の鬱血傾向が 著しく, 特に皮髓境界部附近に执いては毛細血管壁の破 綻性出血像学見ることが出来る (第 26 圖).

腎洞部の太心血管系飞も内膜の肥厚像が見られ, 又血 管周囲結合織或い注時に脂肪織内に小円形細胞浸潤が証 明され, この細胞浸潤は弓狀動靜脈, 或いは小葉間動靜脈 周团結合織认於いても連続的乃至断続的飞証明される.

第 7 例. 関○某, 60 才우. 初診 : 昭和 33 年 6 月 28 日. 既往歷及び家族歴：特記すべきものはない。

現病歴：20日前より無症候性血尿に気付き次第に増強 の㑯向学認め来院した.

現症 : 兩側腎共に触れず, 圧痛も認めない，尿は赤褐 色溷濁尿で, 沈渣は赤血球 ( $($ I), 白血球 (土), 上皮 (一), 細菌 (一). 膀胱鏡检查 : 右尿管口より血尿の排出を認め る. 膀胱粘膜に異常所見を認めない. インデゴカルミン 試驗: 左 3 分 25 秒で初染し 4 分で濃青となる. 右注 3 分 45 秒で初染し 4 分 30 秒で濃青となる.

治療：種々の保存的療法学行引も効無く, 昭和 33 年 7 月13日右腎剔除術を行つた.

経過: 術後血尿は全く消失し, 昭和 33 年 8 月 15 日全治 退院し以後再発を見ない.

\section{剔出腎肉眼的所見}

大きさ $13.5 \times 6.1 \times 4.5(\mathrm{~cm})$, 重量 $131 \mathrm{~g}$, 表面は略 々平滑で, 被膜は容易に剥離出来る. 割面上髓質部に於 いて乳頭を中心とする放線狀に搌がる暗赤色の血管走行 数條を見る. 腎孟粘膜は異常所見を認めない.

病理組織学的所見

腎盂腎杯部: 腎杯粘膜上皮細胞 向, 或いは不規則性配列等が著しい. 粘膜下組織は結合 織性肥厚が見られ, 同時に血管周因性小円形細胞浸潤及 びリンパ滤胞様細胞集簇群を認める部位もある. 毛細血 管の擴張が著明な部に於いては腎杯壁全体に浮腫傾向之 下腎杯では更に漏出性出血像も認められた。然し多くの 腎杯壁は結合織線維の增生己同時に筋線維の萎縮消失の 結果腎杯壁全体としては学しろ菲薄化を示し，特に螺旋 動脈の著明なる変性部に於いては，腎杯粘膜下層自体に 著明なる結合織性増生並びに硬化傾向を伴い，一見腎杯 壁つ硝子変性を思わしめる像を示す。又該部に於いては
螺旋動脈々周囲結合織の間に組織間隙が認的られ，同時 に層狀に横に擴がる出血巢を証明出来る (第27圖).

腎実質 : 皮質内血管系は内膜肥厚, 迂曲傾向が著し く, 又血管周囲結合織内に小円形細胞浸潤が認められ る. 糸球体の硝子変性像軽度ながら散見される.皮髓 境界部に於ける弓狀動靜脈周囲結合織内に於いても結合 織の増殖傾向と小円形細胞浸潤が認められる. 又㵦質毛

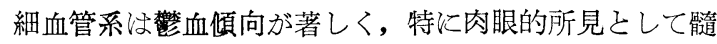
質内を放線狀に走る血管と思われた線條は, 組織学的に 注毛細血管系の高度擴張乃至血管壁破綻像を示した。出 血部の周囲結合織は比較的所見に乏しく, 集合管内腔に 赤血球の存在する場合は極めて少い。乳頭部の血管系は 部分的な擴張狀態及び間質結合織の増殖, 並びに部分的 な浮腫が認められ, 又間質の石灰沈着傾向が著しく, 石 灰沈着部附近浮腫或いは細胞浸潤を随伴する傾向が見 られる. 集合管上皮細胞は可成り配列が不規則となり， 剝離傾向を示す部分も存在する.内胿は時に硝子様円柱 の存在することもあるが, 血球要素ふ証明出来ない。

督洞部血管系の中螺旋動脈法特に硬化性乃至膨化性变 化が著明で, 周囲組織には小円形細胞浸潤を伴つている.

組織内細菌染色により病原菌注証明され沙い。

第 8 例. 泉某, 57 才里. 初診：昭和 33 年 7 月 5 日.

既往歷及び家族歴: 特記すべきものはな。

現病歴：2 週間前より血尿老認め次第の増悪の傾向定 認める。

現症 : 兩側腎共に下極を良く触れるが, 表面は平滑で 圧痛を認めない. 尿は純血性润濁尿で凝血を混ずる. 沈 椬法赤血球 (卅), 白血球 $(+)$, 上皮 (十), 細菌 (一). 膀 胱鏡检査 : 左尿管口ょり血尿の排出を認める. 膀胱粘膜 ふ正常であるが底部に拇指頭大の凝血を 1 二認める.イ ンジゴカルミン試驗: 左は 4 分で最初から濃青, 右は 3 分 30 秒で初染し, 4 分 45 秒で濃青となる.

治療: 輸血, 止血郕投與によるもの血尿高度で, 時に 排尿障害を認めるため, 昭和 33 年 7 月 25 日左腎剔除衍定 行つた.

経過: 術後血尿々消失し, 昭和 33 年 8 月 13 日全治退院 し, 以後再発を見ない。

剔出䝳肉眼的所見

大きさ $12.5 \times 5.8 \times 4.5(\mathrm{~cm})$, 重量 $132 \mathrm{~g}$, 表面注平 滑で被膜注容易に槑離出来る. 割面上腎実質及び腎㙉粘 膜共に異常所見を認的ない。

病理組織学的所見

腎孟腎杯部：腎盂腎杯部移行部附近の粘膜上皮以稍々 増殖傾向を示すが, 個くの細胞は退行性変化が著明であ 
る. 粘膜下層は一部に小円形細胞浸潤を伴う部も存在す るが, 大部分は結合織性肥厚, 或いは限局性の痏痕化傾 向を示し，該部の変性を伴つた螺旋動脈との間に見られ る組織間隙に出血巢を証明出来る．更に該部へ到る螺旋 動脈を連続的に追跡した場合, 粘膜下組織の外層部に於 いて，同血管壁には石灰沈着を伴つた特異な变性像を見 るここが出来る. 即ち同血管壁中膜に一致して環狀に石 灰沈着が認められ，所謂石灰板形成の狀態を示した（第 28圖).

との様な組織像は該腎杯を除いて他の腎杯では証明さ れず。又腎実質内血管系に於いて污斯る变化は認められ ない。

䇛実質：皮質に於ける病的所見は乏しく，糸球体の硝 子変性と周囲間質の限局性細胞浸潤, 中小動脈内膜の犱 厚及び周囲組織内小円形細胞浸潤を散見するに過ぎな い. 髓質注間質結合織の增殖が見られ, 又限局性浮腫或 いは囊胞形成を認める. 毛細血管系の擴張傾向は軽度で

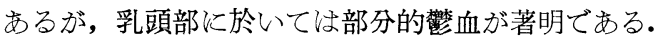

腎洞部に於ける太い血管系には特記すべき所見はな w.

組織内細菌染色により病原菌は証明出来ない。 [小括]

第 $6,7,8$ 例の 3 例は比較的高令女子に見られた腎出 血症例で， 3 者の示す組轼学的態度にも共通する点が多 い. 即与皮質を含む腎全体の血管系に老年性の变化を認 めるが, 就中最も変性の著しい血管は螺旋動脈であり, その中に注石灰板形成を伴了症例もある。Cの様な強い 变性学示す血管の分布領域即与腎杯壁况, 限局性の硬化 性或いは瘢痕性結合織増殖が見られ，又殆んどの場合筋 線維梳萎縮消失傾向を示す。この様な組織変性を伴う腎 杯壁注，腎杯角或いは方の他の部位特に変性血管の周囲 で組織裂隌を生じ，毛細血管破綻性の出血が認められ る.一方腎杯壁に於ける該硬化性病变部の周囲組織はむ しろ浮腫性で, 毛細血管の擴張傾向が著しく, 同時に漏 出性出血を伴い，乙れは粘膜下出血へと発展する. 然し 毛細血管擴張㑯向々該部以外の腎杯, 髓質或いは乳頭部 に於いても認められ，同時に間質結合織の増殖，部分的 浮腫, 粟胞形成, 石灰沈着像を伴う場合が多く, 又髓質 毛細血管系には破綻像を認めるここがある.

第 9 例. 西某, 46 才。. 初診 : 昭和 31 年 2 月 29 日.

既往歴及び家族歷：特記すべきものはない。

現病歴: 約 7 力月前示ら血尿宅認め, 以後今日まで程 度の差洨あるが殆えぞ持続的であり, その間 1 度左腎部
に疝痛発作を認めた以外に注自覚症を認めない。

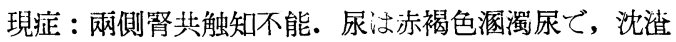
经赤血球 (卅), 白血球 $( \pm)$, 上皮 $( \pm)$, 細菌 $(-)$. 膀胱 鏡檢査 : 膀胱粘膜正正常であるが，左尿管口より血尿の 排出定認める.インデゴカルミン試驗：左泳 2 分 31 秒で 濃青となる. 右は 3 分 45 秒で初染し, 4 分 02 秒で濃青己 なる。

治蹽 : 種々の保存的療法の効なく, 昭和 31 年 3 月 23 日 左腎剔除術学行つた。

経過: 術後血尿以消失し, 昭和 31 年 5 月 4 日退院し, 以後再発定見ない。

剔出腎肉眼的所見

大きさ $11.5 \times 5.8 \times 4.5(\mathrm{~cm})$, 重量 $132 \mathrm{~g}$. 表面に軽 度の凹凸めり，被膜は稍々肥厚し利離困難な部分があ る。筒凸面より正中割面を入れると，腎洞部の脂肪織内 に血腫を認め，これは 2 コの中腎杯门粘膜下に及んでい る. 粘膜面より見ると， 2 コの中督杯を中心として更に 腎孟面にも擴がる粘膜下出血でをり，特に粘膜面に膨隆 する傾向々ない，腎実質には殆えざ变化を認めず，下極 に小豆大の囊胞を 1 コ認める.

病理組織学的所見

腎孟腎杯部：全般的に粘膜上皮々軽度の退行性変化を 認める. 粘膜下層は浮腫傾向が著しく, 又軽度ではある が血管周囲性円形細胞浸潤を認める。腎杯角汇見ら礼る 組織の間隙部走䖝球の層狀の浸潤が証明さ㣗，一部汸 腎杯角の組織間隙部を更腎杯腔内迄流出する像を見 る. 更に出血巢走連続的に追跡すると, 腎洞部脂肪織内 の出血菓に到達する。

この部の出血巢は高度且つ廣沉で，腎杯壁後面の脂肪 織を横に擴がり腎盐壁後面に達する。出血巢はこの部で 血腫を形成し，へモジデリン沈着を伴つている．腎杯角 に近い部で膨化性变性を伴つた腎洞部螺旋動脈が出血巢 に一致して孤立性に存在し, 内脘には血球成分を欠き, エオジンに淡く染る液狀物質导認める (第29圆).

腎実質 : 皮質血管系は内膜の肥厚已迂曲性走行を示 し，上極部に於いて贸狀の撗がりを有する間質炎像学認 めるが, 出血性变化は証岄出来ない (第 30 圖).髓質に於 いて間質結合轼の增殖が著明で，集合管の擴張傾向或い は襄胞形成が認められる. 乳頭部毛細血管以拱張を示す が出血傾向は認められず，集合管内に硝子円柱の存在字 見るも赤血球その他の血球要采泣証明されない。

[小 括]

本症例の特徵として, 肉眼的に 2 二の中腎杯定中心と する腎洞部の血腫形成を認めた点安擧げるととが 出来 
第 1 図合成樹脂注入法で得た腎動脈鋳型。左右を 緶に走る葉間動脈から分枝し，特暴な螺旋状走行 を示しつ>腎杯部附近に集る血管系が螺壻動脈で まる。

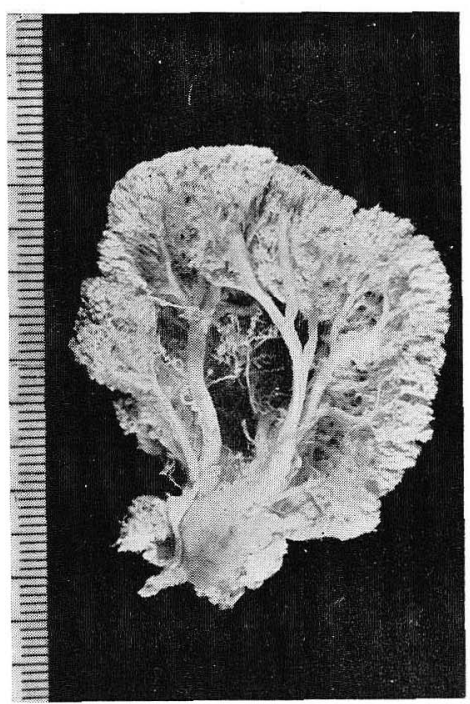

第 2 図螺旋動脈抾大図

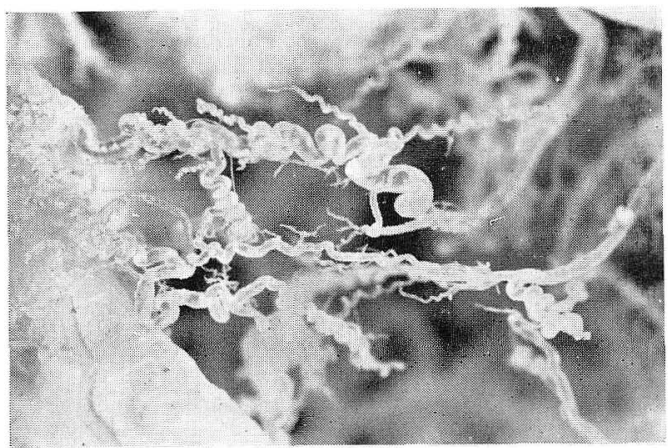

第 3 図標本の切り出し法

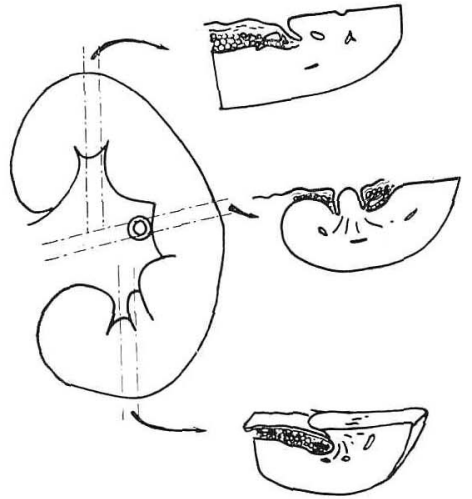

第4园（第1例）腎杯角附近に於ける出血と初期 药芽形成像 $(\mathrm{H}-\mathrm{E}$ 重染色, ×20)

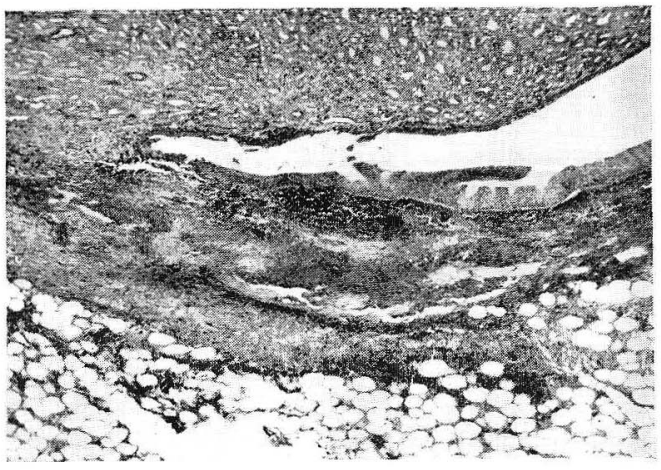

第 5 図（第1 例）腎杯部战膜上皮が䀩々正常である のに反し，粘膜下固有層に於いては出血並びに小 円形細胞を主体とする著明な細胞浸潤と血管壁の 硬化性変化見る。又外層に於いて断続的配列孝 示す血管系は健康な螺旋動脈で岁る（H-E 重染 色, $\times 50$ )

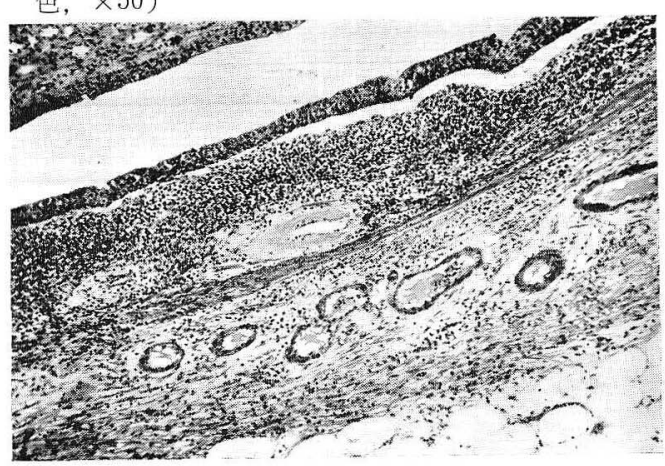

第 6 図（第1例）皮質に於け石硬化性間所炎像 (H-E 重染色， ×50)

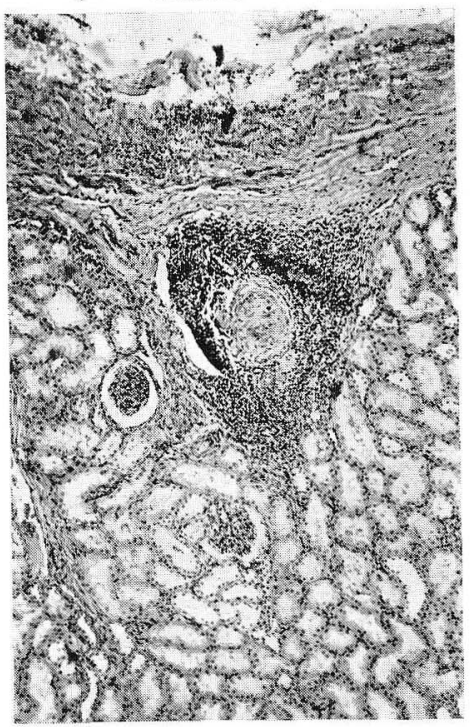


第7 図（第２例）腎杯角の限局性瘷痕形成（遊徼㑯 向が窺える）々周囲毛細血管の拡張。（H-E 重 染色, $\times 50$ )

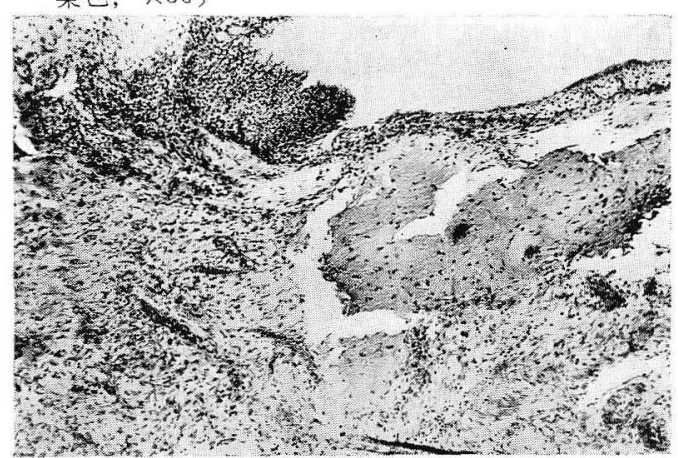

第 8 図(第2 例) 蠌旋動脈の变性像並び飞粘膜下 組織の浮腫及び細胞浸潤。(H-E 重染色, ×50)

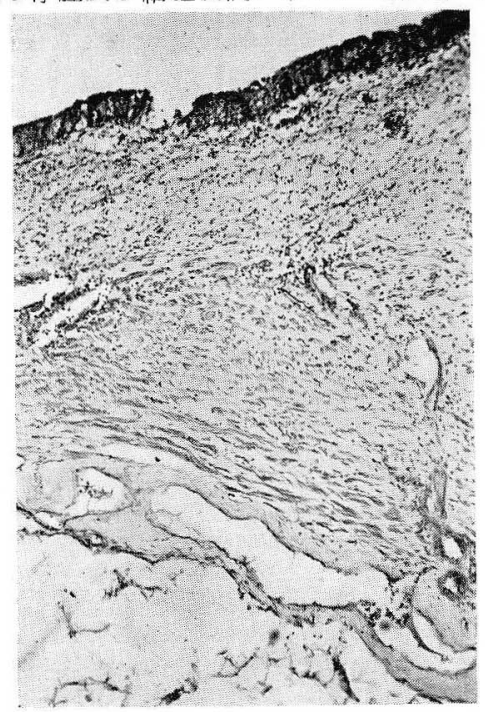

第9园（第 2 例）Bertin 腎柱結合織内に見られ る変性を伴つた螺损動脈（上方を横に走る）と健

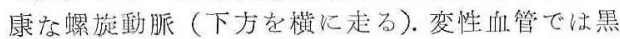
色に染名奵銀線維の消失が芫られる。(Gomori 氏鍍銀染色, × 100)

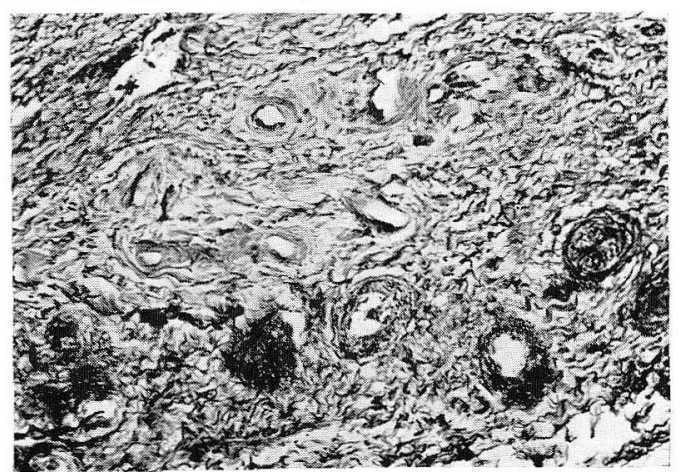

第10戍 (第 2 例) 同変性血管に於ける弾力線維の 態度 (Weigert 氏染色, $\times 100)$

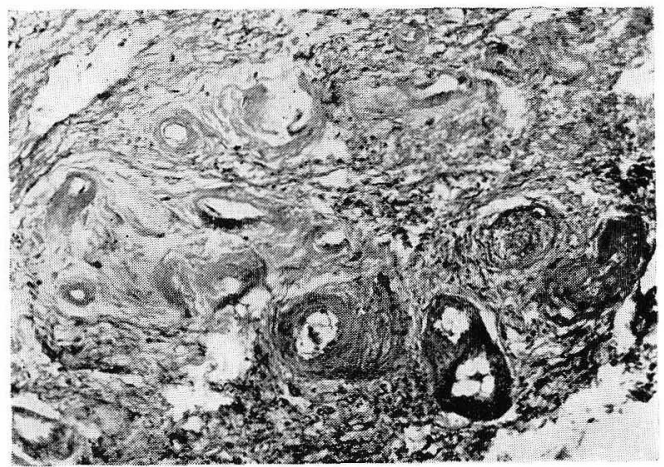

第11図（第 3 例）腎杯壁の結合織性硬化像と硬化 性変性を伴つた螺旋動脈。两者間の組織閒隙には 出血少が認められる。（H-E 重染色，×50)

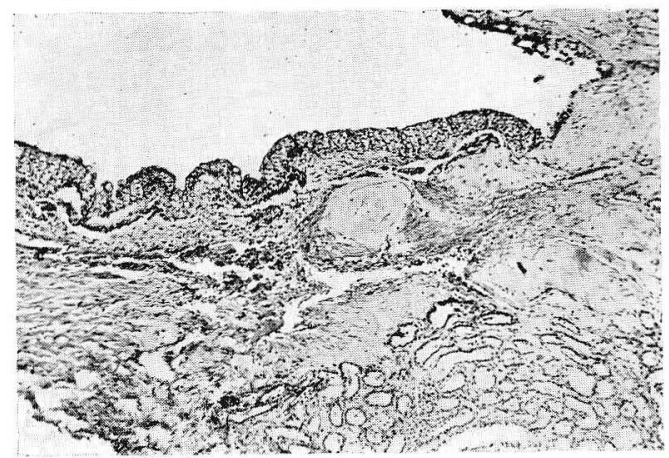

第12図（第3 例）粘膜下固有層の浑出性出血支伴 つた毛細血管抾張像，並びに外層に於的る螺损動 脈の硬化性变性像。左隅は出血, 久小形細胞浸潤. (H-E 重染色, ×50)

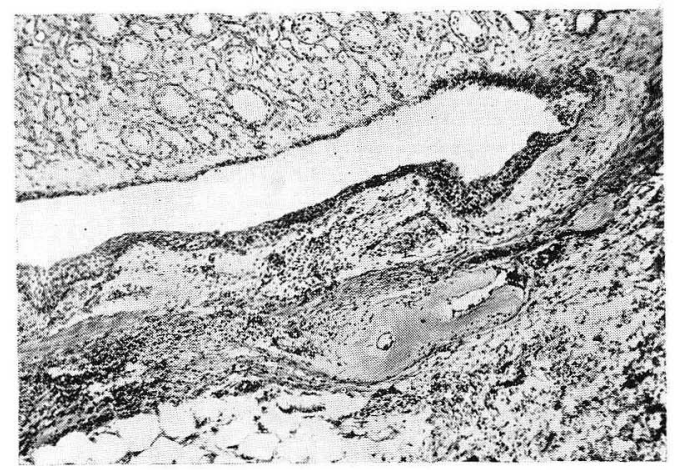


第13図（第 3 例）皮質に於ける限局性糸球体出血 像 (H-E 重染色, $\times 50)$

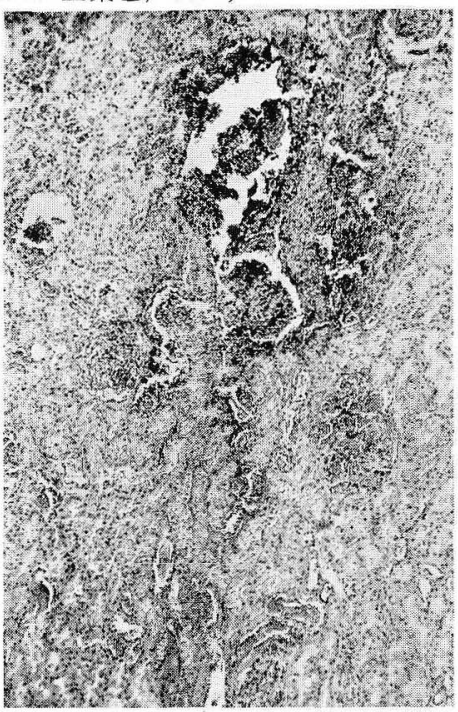

第14図（第 3 例）乳頭部に於ける囊胞形成を伴つ た間質結合織增殖 (左力) 及び浮腫 (右方). 同部 の集合管及び毛細血管は部分的なくびれと迂曲傾 向を示す．（Goldner 氏変法，×100）

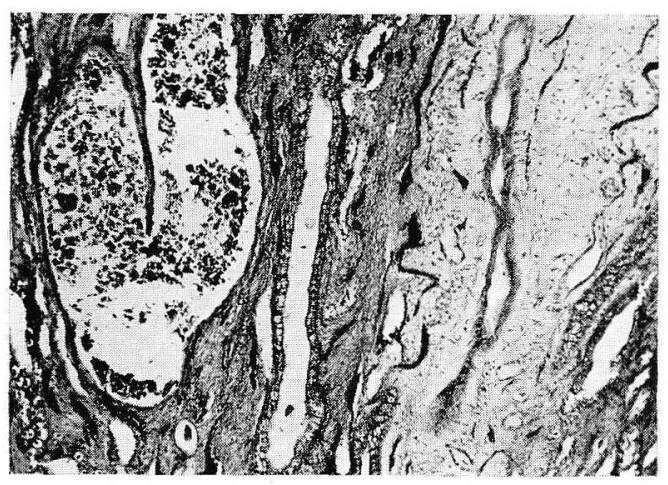

第15図（第 3 例）乳頭部に於ける出血索伴つた石 灰沈着剥離像。(H-E 重染色, $\times 50)$

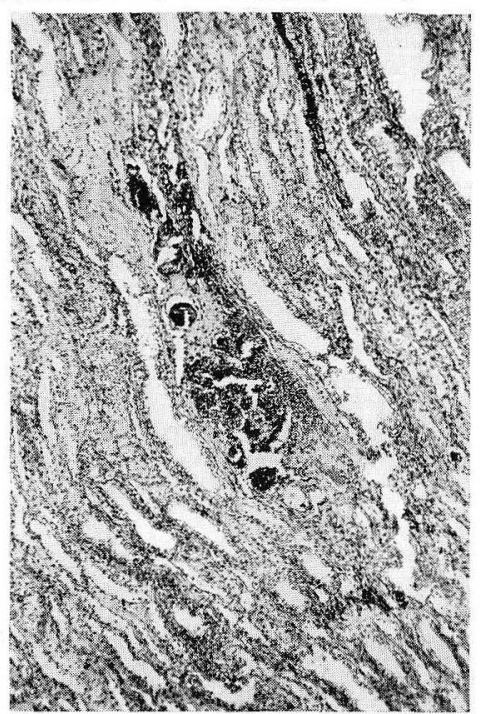

第16図 (第 3 例) 慢性增殖性静脈炎像. 右下方は 乳頭及び腎杯部で岕。( $\mathrm{H}-\mathrm{E}$ 重染色, ×20)

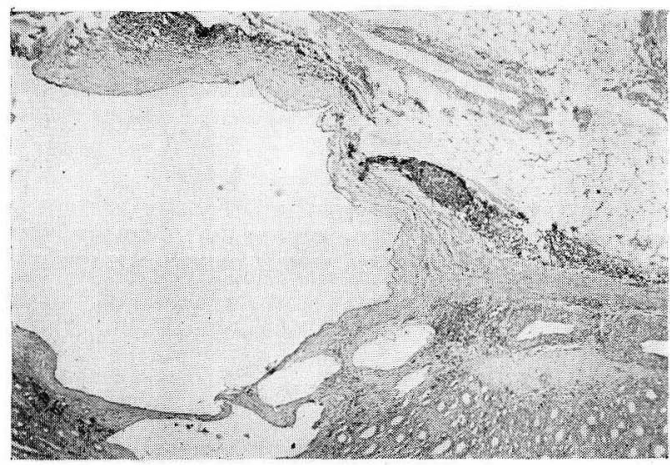

第17図（第 4 例）腎杯角に於ける出血及び細胞浸 潤, 粘膜直下にす小出血巣が見られる。(H-E重 染色, ×50)

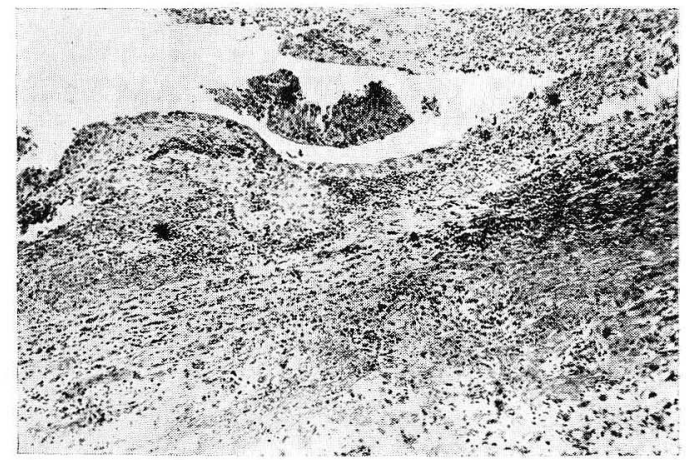


第18戍（第5 例）毛細血管の抎張及び粘膜下組織 の浮腫。螺旋動脈は充血傾向示す。（H-E 重 染色, $\times 50$ )

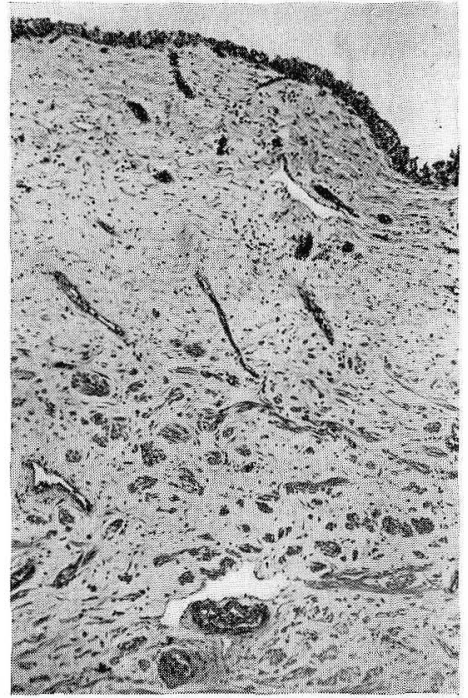

策19図（第5例）腎杯角《於ける結合織性硬化像 そ，組織間陌に見られる出血盖は粘膜下にぬで拡 がつている. (H-E 重染色, ×50)

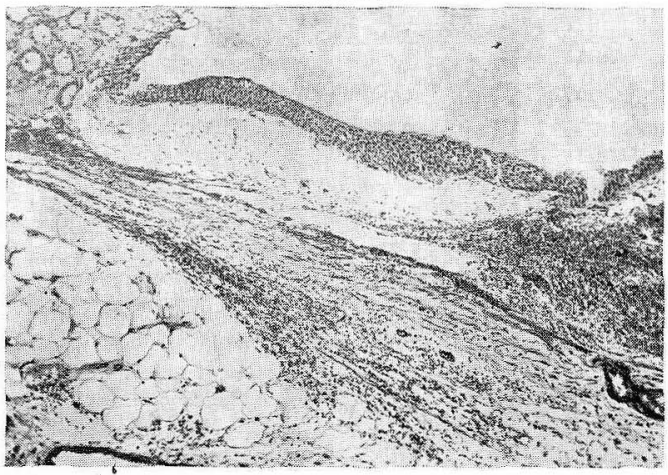

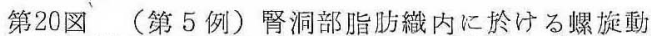
脈之著明なる䌚血傾向を示す同部静脈( H-E 重 染色, × 100)

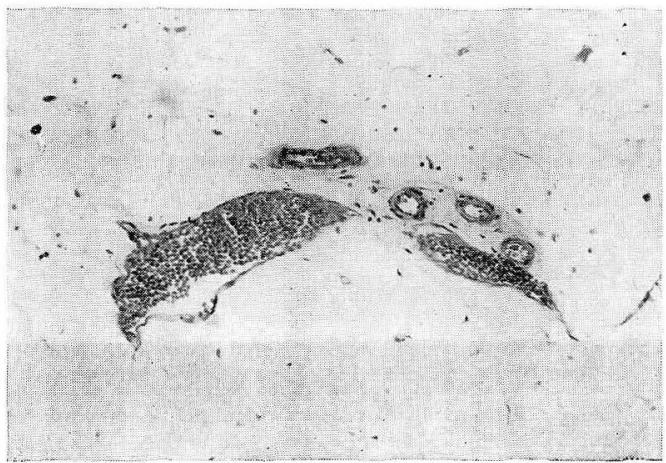

第21図 (第6 例) 粘膜上皮内細菌群 (Goodpasture 氏法マッカラム変法, × 400)

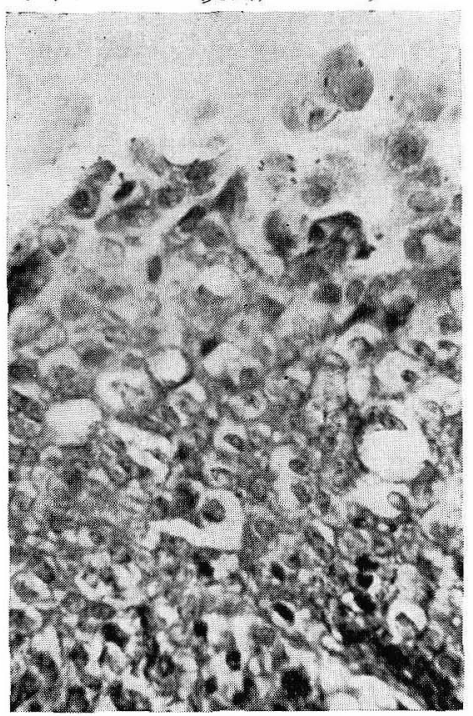

第22図（第6 例）螺旋動脈の硬化性装性:並びに

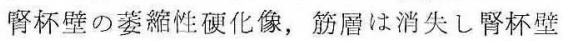
の翡薄化傾向が著しい。（Masson 氏 Trichrome 染色, $\times 50$ )

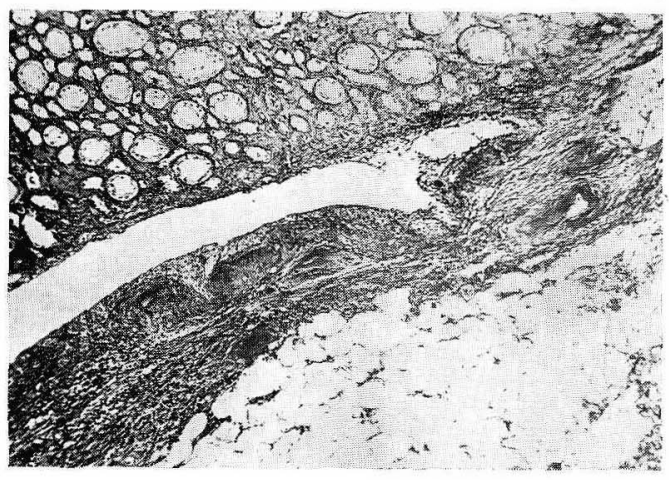


第23図その1（第6 例) 腎杯角重裂部からの出血 像之同部変性螺揟動脈.

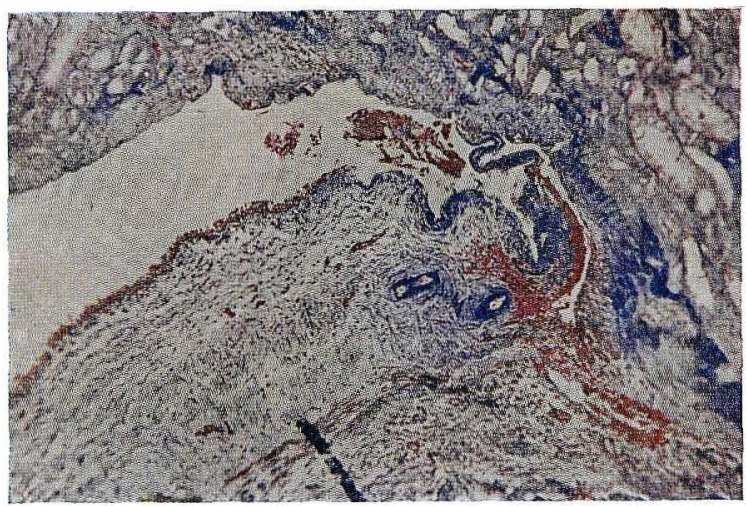

第23図その2（第6 例）Bertin 氏腎性絬合織 内に於ける乑旋動脈の变性像.

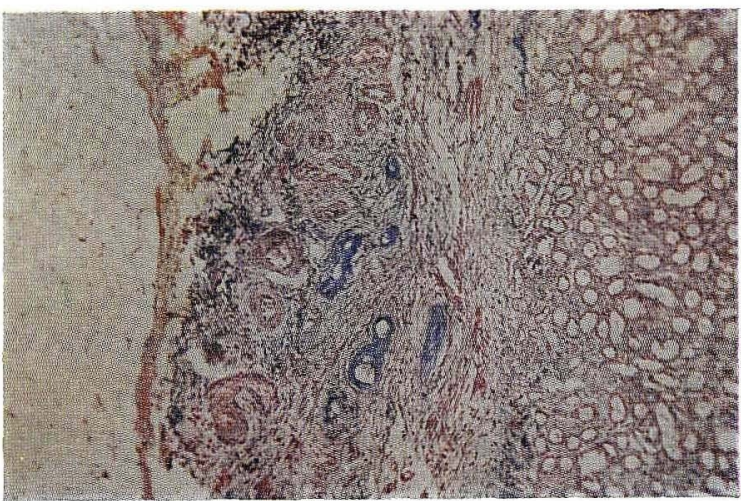

（その 1，2 共に Masson 氏 Trichrome 染色， ×50）

第24図（第 6 例）腎杯粘膜下層に於ける毛細血管 拡張々漏出性出血. (H-E 重染色, $\times 50$ )

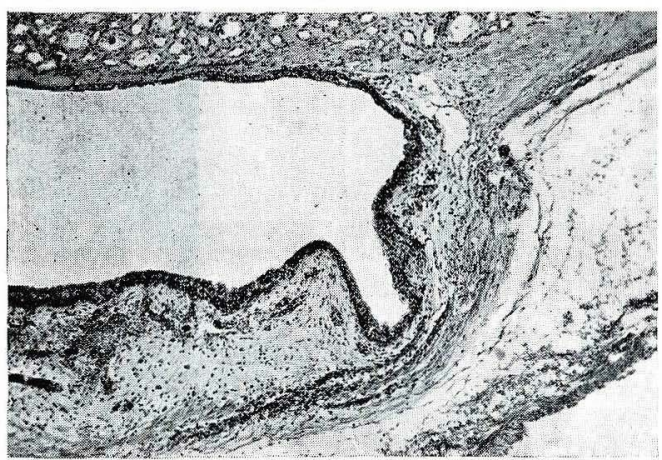

第25図(第6 例) 第24図の桩大：粘膜下出血像 (H-E 重染色， X 100)

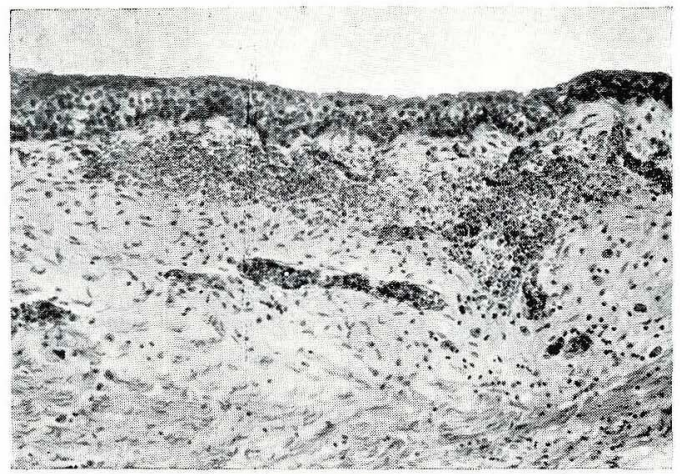

第26図(第6 例) 皮随境界部附近に於山る毛細血。

管の扗張及び破綻像（Goldner 氏変法，×50）

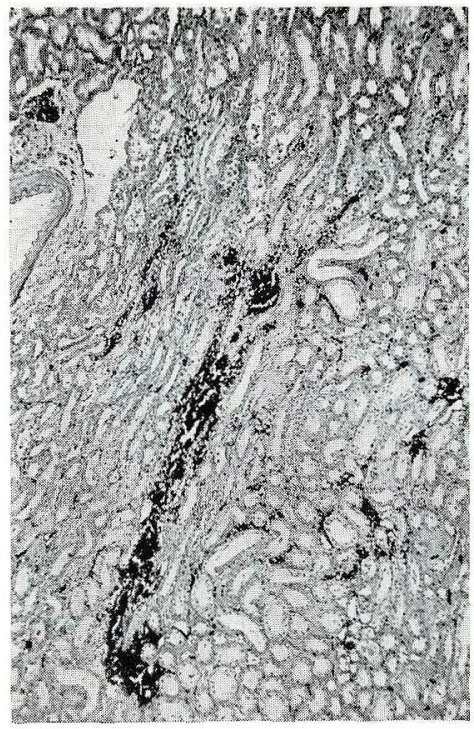

第27図（第 7 例）腎杯角附㳋の出血及び腎杯粘膜

下組織の著しい硬化像並びに同部の螺旋動脈に見

られる硬化性変性像. (H-E 重染色, ×50)

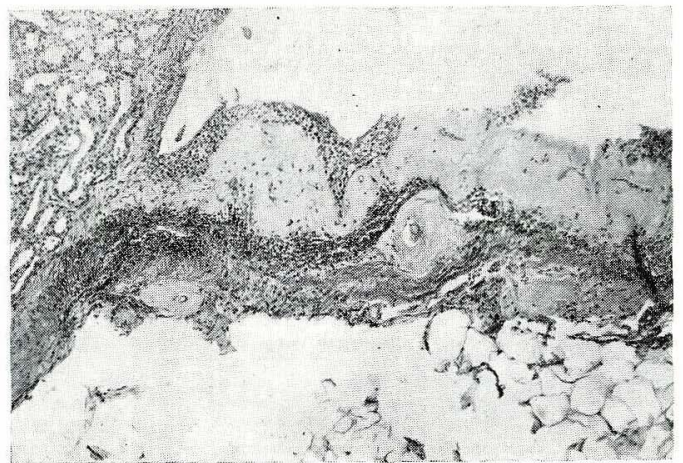


第28図（第8 例）螺㺼動脈壁の石灰板形成像。粘 膜下組織は結合織性硬化像を呈し，变性を伴つた 血管の周囲組織間吵に出血㮺を見る。（H-E 重 染色, $\times 50$ )

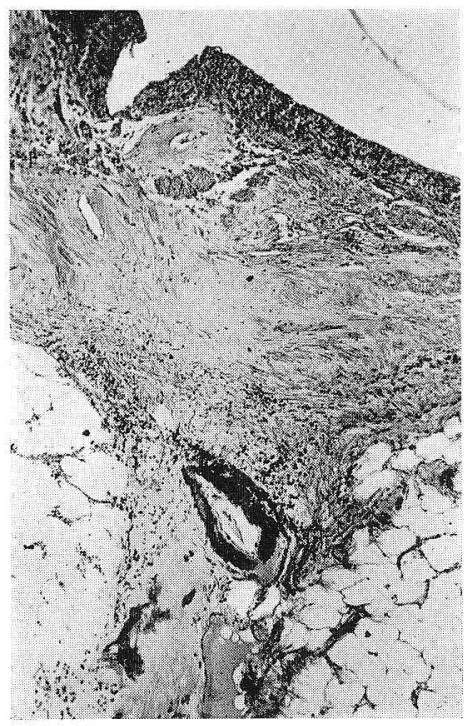

第29図（第 9 例）腎洞部に於怡る強い出血と変 性を伴った螺旋動脈．該血管内腔は血球成分を欠 除する。（H-E 重染色，×20）

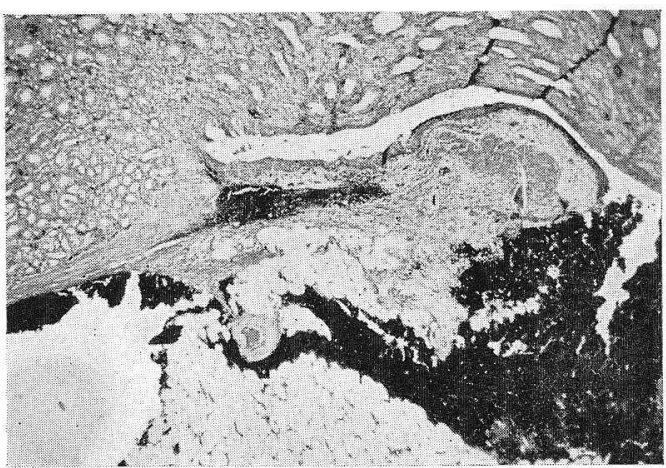

る. 組織標本作製㭙組織切片が出血集で離断し，直接血 管摃傷部定連続切片中に証明出来なかつたが，出血巢が 手術操作の比較的加わらない腎洞部に限局している点, 及び出血樂の中心強い変性学伴つた, 而かも内腔に血球 成分を全く欠いた螺旋動脈が孤立性に存在する点なざか ら, 本血管の更に上流に於ける損傷部の存在学推測さ 出，又筲杯部に見られる様に腎洞部出血巣が組織間隙面 学通して腎杯腔内え流入する場合も存在するこ己学物語 る症例亡考光たい.
第30図（第 9 例）硬化性間質炎像 (H-E 重染色, $\times 20$ )

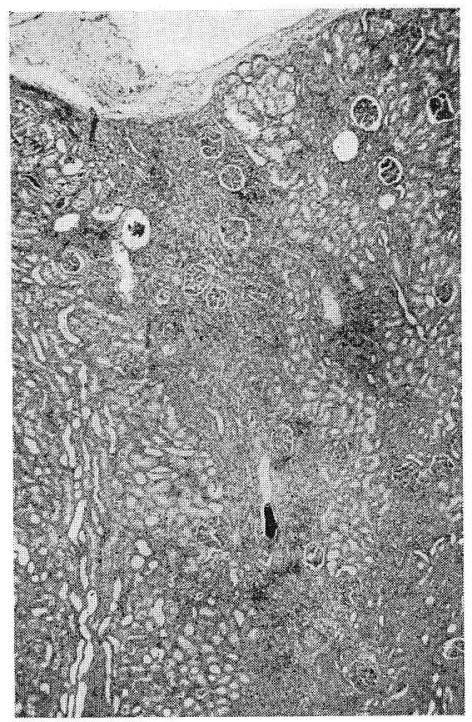

VI. 総括並びに考按

A. 病理組織学的所見の恣とめ

以上 9 症例につき, 督各部に於ける重要所見を要䄪し て次に示すを，

1）督杯粘膜上皮は退行性変化学見る場合が多く，時 に粘膜上皮周内に赤血球或いは白血球の介入学認め，又 上皮虽離傾向，慢性炎症性増殖学示守場合も方る。

2）腎杯粘膜上皮層に較べ粘膜下組織の変化は顯著で 施り，同部の毛細血管搌張，出血，肉芽形成，結合織増 殖, 誐痕形成乞云つた一連の組織反應像と, 解層の萎縮 退化学主体己した腎杯壁の菲薄化傾向，更に部分的或い は全体的に見られる浮腫傾向，その他小円形細胞を主之 与る血管居囲性或いは集簇性細胞浸潤等極めて多彩な組 織像が見られる。

3）腎杯壁の組織変性部に見られる螺旋動脈々著しい 血管壁硬化像学示し，時血管壁の石灰沈着学伴う場合

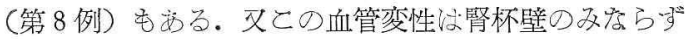
腎洞部 Bertin 氏㯏柱結合織内にも証明せられ，内腔 は狭小化し，血球成分学殆んざ久除する。猶扔との血管 壁硬化性変化注全症例共螺旋動脈特有のものであり, そ の他の腎内血管系に问変化証明出来ない。

4）腎杯壁に於ける組織所見は螺旋動脈の変性と極め て深い関係学有し, 螺旋動脈の硬化性变化の多く見られ る腎杯宝ざその壁の菲薄化傾向が強い。

5）䐌杯壁に於ける出血の種類汸，毛細血管漏出性出 
血及び破綻性出血で, 出血の大小と蠌旋動脈の变性の強 弱との間に畆直接的な関係は認められない。

6）腎杯壁の炎症性变化が腎杯角に接して存在する太 い靜脈壁周囲結合織にまで波及し, 靜脈壁に炎症性変化 をもたらす場合（第 3 例）がある.

7）血管周囲性小円形細胞浸潤或いは結合織増殖傾向 は, 腎洞部より葉間動靜脈, 弓狀動静脈, 更飞小葉間動 靜脈周囲に至るまで連続的或いは断続的に追跡出来る。

8）皮質の変化は比較的軽微で, 軽度の血管内膜肥厚 認めるもの（第 $1,2 ， 6 ， 7 ， 8 ， 9$ 例), 又皮質飞 贸狀の硬化性間質炎像（第 $1,2,5,9$ 例）を認める 場合もあるが, 糸球体, 'Bowman 氏露, 尿細管注正常 の場合が多い，但し第 3 例に於いては皮質に限局性糸球 体出血像学認めた。

9）皮質に較べると髓質並びに乳頭部の变化は著明且 つ多様性である。即与髓質特に皮髓境界部附近に毛細血 管の擴張（全症例）或い涊破綻像（第 $2 ， 3 ， 5,6$ ， 7 例）を認め, 同時に乳頭部に於いて注毛細血管の部分 的擴張, 間質刀浮腫, 結合織增殖, 石灰沈着 (第 3,7 , 9 例), 霬胞形成（第 $2,3,7,8,9$ 例）を見る.

な抢病理組織学的檢索によつて得を各腎儿於ける主要 所見の部位的関係を一括して見取圖で示した (第 1 表).

出血性変化を証明し得る腎杯部は，各腎に於いて 1 個 或いは 2 個で，その障害された腎杯の部位的特異性注証 明されなかつた。同一腎に於いて全く病的所見を認め ない腎杯も存在した. 髓質の毛細血管撗張或い淰破綻像 の著しい症例では, 間質結合織の増殖が強く, 又石灰沈 着, 賈胞形成も著しい傾向を示した.

B. 病理組織学的主要所見についての考察.

1. 螺旋動脈について

腎動脈内合成樹脂注入法で得た腎動脈鋳型標本に於い て, 腎杯部附近に注特異な血管構築即ち螺旋動脈が存在 し, 又本血管は腎直達血管系の 1 つで, 腎孟腎杯部の栄 養血管であると同時に腎血流量調節を司る重要な血管で あることは既に述べた，一方見方を変えれば，本血管は 腎盐腎杯部の栄養を司る作用以外飞, 腎血流量調節とい ろ余分な働きを強いられる負擔の大きい血管系とも見做 し得る. 更に解剖学的立場から見た場合, 葉間動脈とい う比較的大動脈に近接した太い血管心ら直接分枝してい る点, その分布領域仙尿排出運動を營を関係上，常に被 働性を強いられる点等から, 他の腎内血管系に輘べ比較 的若年者に於いても血管壁変性を蒙り易いこと注当然考 え得るところである。
本血管の病態生理に関しては, 近年 Baker が本血管 の分枝は腎乳頭部の血管系と吻合するとの假説のもと に, 螺旋動脈の血行障害を壊死性乳頭炎の原因として考 えている.腎出血の病理組織学的研究の中にも, 腎杯部 血管壁の硬化性変化 (新井), 肥厚及び膨化像 (巾) 在 認めている報告があるが，之等の変化は周囲組織の炎症 性変化に続発したものと解釋されている． Günther は 腎出血症例の病理組織学的研究に於いて, 特儿腎孟腎杯 部を詳細㳊检索した結果, 腎盂と腎杯移行部附近の粘膜 下組織の中に一種独特の型（コルク栓拔き様）を示す血 管方存在し, 或る種の腎孟炎に於いて特にての血管壁が feine faseriger Sklerose と Hyalinisierung を示す 傾向を認めているが，それ以上の詳しい記載はない。

自驗例の病理組織学的檢索の結果, 腎血管系に於いて 最も著しい血管壁変性の認められたのが螺旋動脈である 点以注目に值する. 又血管壁変性浽腎杯壁の炎症性変化 部に限局するものでなく，腎洞部更に Bertin 氏腎柱結 合織内にまで同様变性を伴う螺旋動脈导追跡し得たとと は, 本血管の変性が少くとも 1 分枝單位の系統的变性学 意味するものと考える. 又との組織所見は，血管壁特に 中膜に於ける結合織線維の増殖を主とするもので，本血 管壁の特徴とも云える中膜筋線維次減少乃至消失し, 同 時に彈力線維も失われ, Masson 氏 Trichrome 染色で 青色, Gomori 氏鈸銀染色で黄褐色を示方膠原線維の增 殖, 即ち動脈硬化性変化が証明された. この様な血管壁 の変性は各症例を比較した場合, 年令的な特異性汶認め られず，比較的若年の症例（第1例，27才）に於いても 可成り高度の硬化性变性像を見ることが出来と. 又第 8 例に於いては中膜に一致した石死沈着省認め, 所謂石成 板形成の像を示した. 同時に該变性血管々内腔の狭小化 が著しく, 殆んぞの場合血液成分を欠除し血行障害の存 在を窺い知ることが出来た. 以上の如き螺旋動脈の硬化 性変化㳂次汇述んとする㛑杯壁の組織变性と少なから妏 因果関係を認める点で, 白駩例全例に於汀る病埋組織学 的所見の中でも特に重要覙さるべき所見と考える。

\section{2. 腎杯壁について}

腎杯壁に於ける出血の問題後述するとして, こ〉で は腎杯壁組織像について考察する. 即与 自驗例 9 例の 中, 第 1,4 例に於いては比較的新しい出血巣 が存在 し, 惄杯粘膜下固有層, 筋層, 外膜, 脂肪織に擴がる線 維素の析出, リンパ球, 組織球, 線維芽細胞等の出現は 所謂初期肉芽形成像を示すもので, 同時に出血性壊死巢 を伴つた Quinby ${ }^{71)}$, Mc Kay, Baird \& Lynch ${ }^{722}$ 堀 


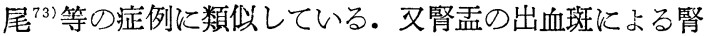
性血尿として報告された症例に対し, 高橋》 は手術操作 による機械的出血と見做しているが, 志賀, Schranz ${ }^{74}$ 黑田 ${ }^{75)}$ ，木根濎 ${ }^{76)}$ ほ反対にてれ学腎出血の原因の 1 つを 考えている. 然し之等の報告に洛腎の個々の腎杯乳頭 部附近の記載が充分でないためこつでば检討学差控え 亏.

第 1,4 例を除く他の症例では, 1 個から 3 個の腎杯 壁飞筋層の萎縮消失傾向乙結合繊線維の増生乃至硬化像 が認められ，その変化は前述せる螺旋動脈の硬化性变性 と略从平行関係を有した。

双て Günther は腎㙉炎腎出血の原因と考え，その 組織像の特徵として督杯部の円形細胞浸潤と浮腫及び硬 化性変化認詢, 新井は腎出血症例 8 例中全例飞腎杯壁 の慢性増殖性又注慢性増殖性炎症性变化已亦, 或い注言 葉を变えて腎杯粘膜下の結合織性肥厚又は結合織性硬化 像を認めたと述べている. 最近巾々腎盖炎の病理組織学 的研究吕ら出発し, 腎性血尿を示した10症例の全例に腎 杯部の細胞浸潤を伴つを粘膜下組織の浮腫々結合織増生

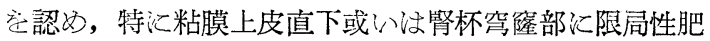
厚部を㕍从認めたと述へててる。

諸家の記載した是等の所見は自驗例に於ける腎杯部の 所見已略々一致するもので, 更に自驗例に於いては，同 時江筋層の萎縮退化傾向が著明であり, 特汇高令女子 (第 $6,7,8$ 例)に於いて注筋層の消失に伴引腎杯壁の 菲薄化傾向が高度であつた。この様な組織变化学 Masson 氏 Trichrome 染色で检索すると青色色調を呈する 線維群，Goldner 氏变法では緑色，又 Gomori 氏鍍銀 染色では淡黄褐色を呈する所摆翏原線維の増殖であり, この結合織線維は該部に存在する硬化性変性を伴つた螺 旋動脈壁の外層結合織と連続的変性を示すかの如き感を 抱かせる。

Günther は斯る組織学的変化の原因として細菌感染 を重視し，その様な意味では Quinby \& Goodpastu$\mathrm{re}^{71)}, \mathrm{Warsch}^{42)}$, Ceelen $^{16)}$, Mc Kay, Baird, Lynch \& Kimmelstier ${ }^{72)}$ も同様の見解を有するが, Bumpus ${ }^{77)}$ も指摘する如く，諸家の報告の中で臨床上或いは組織 学的にその病原菌が証明されない場合も可成り多く, 巾 涊10例中 8 例までに分離尿中に細菌を証明し得なかつた と述べている. 自驗例に於いても 9 例中グラム陰性短桿 菌を認めを例として第 $3 ， 4$ 例を擧げるとこが出来る が, 之等の症例估化学療法により尿中細菌が消失したに も拘らず，猶抢血尿の持続を認めたため結局腎剔除術の
行われたあので, 則出標本について組織内細菌染色を行 つた結果, 兩例共病原菌は証明されなかつた。一方術前 分離尿培養によつて細菌を証明し得ない場合でも，組 織内細菌染色により粘膜上皮内に細菌を証明し得た場合 (第 6 例)もあり，その間の判定極內て慎重を要する己 ころであり, 細菌感染による炎症の合併を全く否定出来 ないとしても，單に組織像のみでその原因を判定するこ との伦險性或い注困離性が考えられる. 然し上にも述べ た如く, 自驗例 9 例中明らか儿組織内細菌を証明し得た の浪 1 例のみで, その他の症例に病原菌字証明し得な かつた事実法，腎杯壁に見られた炎症性組織像の原因己 して非細菌性乃至非特異的なものも存在すると云う有力 な根據を與えるもので，例えば Heine は炎症巢方腎杯 壁の深層に見られるこてろから行性感染を否定し, 又 新井は征前の感染尿つ問題々一只度外視して, 腎杯部て

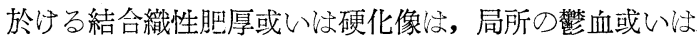
出血の結果壊減せる組織の焂復機轉に因る己考えてい る. 自驗例に於いても出血治始まる肉芽形成, 結合織増 殖, 瘢痕といつた一連の組織变化注当然認めるととろで あるが，一方是等の所見と同時に勜線維の琹縮消失に始 玉る腎杯壁心菲薄化傾向が認められる事実々，同部の組 織像の中に見る硬化性变化を伴つた螺旋動脈の血行障害 に起因与る 1 種の退行性変化の存在も無視出来ない之考 える. 即ち武田 ${ }^{78}$ の著書の中の Fischer-Wasels 等の考 え方に從い，組織の障害が炎症の原因であるとするなら

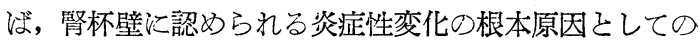
螺旋動脈の血行障害に始宗る種々の組織反應像の解釋も 容易で学り, 從来報告されて来た, 所謂病原菌の証明出来 ない慢性出血性腎孟炎の記載 $\left(\right.$ Lewin $^{37)}$, Schuppel ${ }^{79}$, Scheele \& Klose $^{6)}$, Gottlieb ${ }^{5)}$, Miller \& Young ${ }^{43)}$, Warsch ${ }^{42)}$, Rumpel ${ }^{80)}$ ) が斯る病変の 1 過程を捉えたも のとも解釋できる.

3. 髓質, 乳頭部について

自驗例 9 例中 5 例までに朵遀質毛細血管系特に皮髓境界 線に近い部分の血管壁破綻像が認められ，更に全例に於 いて髓質及び乳頭部の毛細血管鹰張傾向を認めたこと 以，敬出血の構成因子として可成りの意義学有する所見 と云わ䄈ばならない。新井 ${ }^{81}$ 沙腎出血の原因として腎の

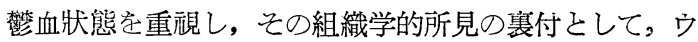
サギを用いて腎靜脈に血流障害を起さしめ，最も早期か ら輥血狀態を示すのは髓質特に乳頭部で，次に腎盂腎杯

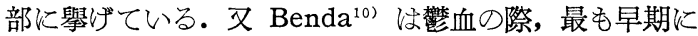

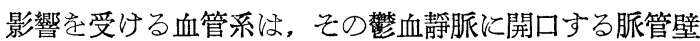
細小靜脈であると述べている。自驗例に於いて髓質毛細 
血管の擴張, 破綻傾向が皮髓境界線, 即ち中心静脈への 開口部附近に於いて特に著しい点流 Benda の説と一致 するものであり，又新井の実驗成績を併せ考えるとき， 自驗例に見られた該部の所見は明らかに籊血狀態を意味 するものと考えられる。

次に乳頭部に見られる細胞浸潤を伴つた間質結合織の 增殖性変化, 並びに部分的な浮腫傾向は同部の毛細血管 擴張略从と平行して認められ，又乳頭部の石灰沈着巢 ( 3 例),集合管擴張及び囊胞形成 ( 5 例) む上記所見に 随伴与る傾向定認めた。

乳頭部の石灰沈着の成因に関しては，乙れを腎結石の 発生原因と考元た Randal1 ${ }^{82)} の$ Calcium plaque 説 を始めとして種々の論議の存するととろであり ${ }^{83)}$, 腎出 血症例に於いて，仁平の云了石灰沈着巢のある症例に於 ける局所性の槐血, 集合管の擴張安示す㑯向は自驗例で も認められたが，更に腎全体を檢索した場合，皮髓境界 部附近或い性腎杯部附近の毛細血管系の擴張が著明であ

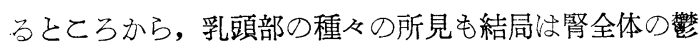
血が原因であり, その随伴症狀として乳頭部の結合織増 殖, 浮腫, 囊胞形成或い社石灰沈着をもたらしたという 見解も一應成立する. 然し仁平の指摘した如く, 1 度発 生した石灰沈着が局所性の槐血を助長し, 更に石灰沈着 老増大せしめる可能性, 並びに斯る局所性悪循環が腎出 血の原因となり得ることは当然推測出来る.

腎の静脈圧六進因子としては從来種くの狀態が考えら れて来たが, 自驗例中特に興味ある症例として先づ第 3 例を舉げることが出来る. 即ち葉間靜脈と腎杯角が極め て接近して存在し, 腎杯角の炎症性变化が靜脈周囲結合 織まで波及した結果, 該靜脈壁の肥厚及び膨化を伴う慢 性増殖性静脈炎による靜脈内腔の狭小化を認めた例であ る。乙の様な変化が腎出血の原因となり得ること指 摘したのは Ceelen ${ }^{16)}$ であり，本邦に於いても岩下50) 纷, 腎孟炎に始まる腎門部靜脈炎が高度の偏側性腎出血 の原因となり得るととを, 自驗例を示して強調してい る. 一方先に述べた Payne \& Mac Nieder の皮髓境 界部の瘕泿形成, 或いは新井の云う慢性增殖性間質炎に よる腎乳頭部の槐血も腎内性因子による腎槐血と云う点 では同一視出来るもので, 軽重の差はあるが自驗例全例 に見られた弓狀動靜脈周囲結合織の細胞浸潤及び結合織 增殖傾向以, Payne \& Mac Nieder 或心注新井の所 見と一致するところであり, 当然斯る狀態が䓂血の 1 因

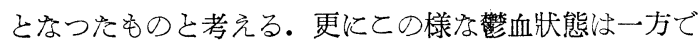
沙周囲結合織の増殖促進因子たり得るところから, 其處
に展開する悪循噮狀態が日常遭遇する持続性血尿の原因 となり得ることは当然考えられる。

次に腎靜脈圧の充進狀態を腎毛細血管圧充進狀態と考 えるならば，岡も指摘した如く腎の充血狀態をもその範 锠に入れて考慮しなければならない。第 5 例々斯る観点 から興味ある症例と考元られる。即与臨床的に全自律神 経緊張狀態を証明し, 剔出腎の肉眼的所見に於いて他症 例に比し暗赤色色調が強く, 血液成分の豊富な感じを與 え，そのことは組織学的に腎各部に於ける毛細血管系の 擴張により証明出来たが, 出血部に於いては他の症例と 異つた点を認めず，腎洞部脂肪織内ではむしろ槐血性の 変化を示した.

今日まで腎の充血性変化を問題こした報告としては, Klemperer に始委る血管神経性腎出血を以つてその代 表と考えられるが，それらの多くは組織学的所見を欠く 名, 或いは出血原因として充分説明出来る所見を欠く場 合が多く, 又本説の裏付として行われて来た動物実驗に 於いても, 腎実質殊飞糸球体に於ける变化の检索に主眼 点が置かれて来たかの印象が強く, 腎杯腎孟に関する所 見の記載注極めてそしい. そのょうな意味では Thelen \&.Wagner の行つた実驗は, 動物実驗で肉眼的血尿莸 得たと云う興味以上に, 检索範囲を腎実質に限定せず, 腎杯腎盂附近まで擴大している点で大いに注目すべき 價值がある. 即ち尿管腎反射による 腎血流障害 (renal vascular shunt) が腎孟粘膜下主として 腎杯窟薩部領 域の浮腫, 充血, 更には出血をむたらしたものであり, 腎 杯穹薩部の充血即与毛細血管圧光進狀態が次の項で述べ んとする出血機轉を成立せしめ得ることを示した貴重な 実驗成績として舉げるととが出来る. 又臨床面から最近 諏訪 ${ }^{85}$ : は, 腎循環障害の病理形態学々題する一連の研究 の中で, 腎皮質血管系の aktıv な收縮狀態法 cortikaler Glomerulus を通る血流量の減少, juxtamedullärer Glomerulus を通り髓質に流れる血液量の増加を 来

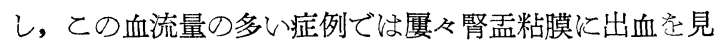
ると述べている.

この様な所謂糸球体血行路を経ない腎内血流の病態生 理, 云い換えれば特殊狀態に置かれた腎の血行動態関 する研究は今日漸くその緒についたと云つても過言でな く, 著者の次に述べんとする出血機序な, その棣な意味 では所謂系球体外腎血行障害病理の 1 端を捉えたものと 考えている.

4. 出血について

自驗例 9 例につき各乳頭を中心に酭質, 皮質, 更に腎 
洞部を含む腎杯, 腎孟を一括して切り出した標本を詳細 飞检索した結果, 明らかに出血巢を思わしめる部位とし て, 腎杯腎盂部, 髓質特飞皮髓境界部附近, 乳頭石灰沈 着剝離部, 皮質限局性糸球体出血の 4 力所を䁷げ得る. この中腎杯腎孟部よりの出血は軽重及び部位的な差ばあ るが全例に認められ, 髓質部の出血は 5 例, その他の出 血法各 1 例に於いて認められた. 更に之等の全例に於い

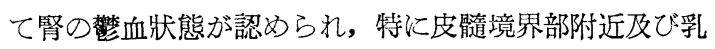
頭部に於ける種々の組織像な, 諸家の見解をも併せ考え

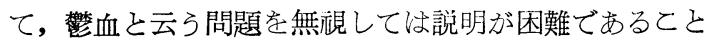
岻既に述べた。

日常臨床面に於いて腎に発生した外傷, 梗塞, 炎症, 或いは腫瘍に㵦伴する出血の場合に, その病変部が直接 尿路面に現われた時に始めて強い皿尿が認められる経驗

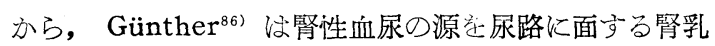
頭, 腎杯部附近に求めているが, 斯る意味に於いて自驗 例全例の答杯壁に見られた出血性变化流極めて重要悓す べき所見と考える. 該部の組織像は, 反復する出血及び その修復機轉, 或いは時に考え得る 2 次的感染によつて 複雜な样相を呈するが, 之等の組織变化と出血との関係 そ論ずるに際しては，同部の栄養血管である螺旋動脈の 存在, 而かも他の腎内血管系には見られない本血管壁の 強い変性の問題, 更に先に迅べた腎靜脈圧立進狀態なぞ 定無視するここ法出来ない。

以上の結果より著者は腎杯壁に於敋る出血機轉を次の 如く考えたい.

螺旋動脈の血行障害は, 未梢毛胞血管網への血行障害 定招来し, 同部の低酸素狀態或い怄栄養障害忟当然毛細 血管壁の透過性を亢め, 更に内膜に於ける内皮細胞間接 合質や間隙の部が開大し, 血液成分の漏出しやすい狀態 が出来上る ${ }^{87788)}$. この様な螺旋動脈の血行障害は自驗例 で示した所謂動脈硬化性変化に基くものであるが，本血 管の特異形態から推察し, 何らかの原因による血管攣縮 狀態も血行障害の 1 因となり得る可能性が考えられる。

以上の沝な螺旋動脈の血行障害によつて発生したその 分布領域即与腎杯壁の一連の組織变性が, 所謂特発性腎 出血に於ける出血発生し易い場 (Locus minoris resistentiae) を形成するものと考える.

即与この様な狀態に於いては腎靜脈圧或いは毛細血管 圧九進狀態に際し, 該部毛細管網に停滞或いは逆流する 血液を容易に血管壁外飞漏出せしめて粘膜下出血を形成 し, 又出血の結果の修復機轉としての組織反應によつて 同部の組織像は更に複雜性を加え（第 1 例の初期肉芽形
成像), 高度の出血の場合には周囲組織の圧迫による限局 性出血性壊死像 (Quinby \& Goodpasture, Mc Kay, Baird, Lynch \& Kimmelstier の例) を呈し, 更に経 過しなものでは腎杯壁の結合織性硬化が著明となり，特 に限局性瘚痕形成が同時に局所の箱血を招き次の出血の 原因となる (第 2 例).次いで斯る腎杯壁つ疲痕萎縮化並 びに血行障害による筋層の萎縮退化等の結果招かれた腎 杯壁の菲薄化傾向は, 尿の停滞或い:腎孟䇕動運動元進 に際し, 督杯角 (第 $5,6,7,8$ 例), 或い法乞の他の 部（第 $3,6,7,8$ 例）の組織間に亀裂を生じ, 毛細 血管破䧑性出血を合併し, 又時には变性の藷し心螺旋動 脈壁から直接出血見る場合も市る(第 9 例).

高橋（1936）快第25四日本泌尿器科学会総会汇於付る 血尿と題する宿題報告の中で, 特発性繁出血法未だ判然

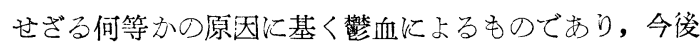

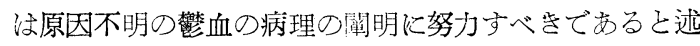

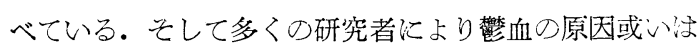
病理に関する問題が種々檢討されて今日に至つている。 然し, 先に述べ如く篮の血行路についてい, 從来の解 剖書にあまり記載のなかつた糸球体外腎血行路つ存在が 明ら加され，その病態生理とも表現出来る所謂 renal vascular shunt (Trueta et al., 渋沢等 ${ }^{89)}$, Thelen \& Wagner), 或い以諏訪の云う aktiv な皮質血管系の 收縮狀態が今日までの吾々の知識で惊説明の出来なおつ た新血行学示唆する可能性も生じ, 若し諸家の述べる如

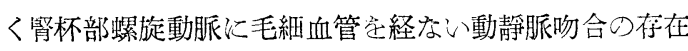
安假定出来るとずるならば, 毛細血管圧六進状態につい ての解釋も一層容易となると考えられる。

以上の様な観点から臨床治療面を眺めた場合, 古くか ら腎出血に対して行うれて来た腎被膜剝離衍, 腎固定術, 交感神経切断術, 硬膜外神経尷断衍等による血尿つ消 失, 或いは自律种経遮断版, 冬眠療法削等の有効性法,

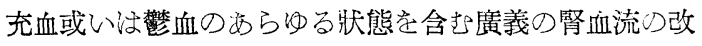
歖より説明出来ると思う. 一方藥物療法の 1 種として, 抗ヒスタミン㓮投與により腎出血の治瘭を見ること沙臨

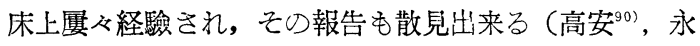
田 $\left.{ }^{911}\right)$. 然しその作用機序については, アレルギー性反仵 自体に多くの未解決な問題が残されているため充尔な解 答法得られないが，抗ヒスタミン郕により其處に展開し つ〉あるアレルギー性炎症を抑制する作用と同時に末梢

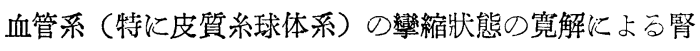
血流の正常化と云う作用も存在するものと考えられる.

又今日まで行われて来た腎孟内薬物注入療法流, 自䲆 
例病理組織学的檢索の結果尔ら考えて所謂出血の場に 対与る局所療法として推賞出来るものであり，な抢注入

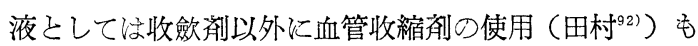
一應試及るべき方法と考えられる。

\section{VII 結 語}

（1）特発性腎出血の病理組織学的研究化先立ち, 合 成樹脂注入法により腎杯部附近の血管構築について研究 し, 該部に腎葉間動脈から直接分枝する螺旋動脈の存在 するとと確認した。

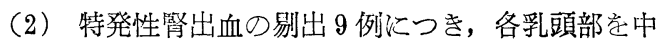
心として髓質及び皮質，更に腎杯腎孟主同一切片に同時 に含む標本の連続切片を作製し，詳細に檢索した結果，

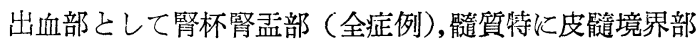
附近 ( 5 例), 乳頭部石死沈着刎離部 ( 1 例), 皮質限局性 糸球体出血 (1例) の 4 者を認めた.

（3）各腎に於ける出血性变化学伴亏腎杯は，1個乃 至 2 個に限られ而かも部位的特異性流なく, 何れも該部 に至る螺旋動脈に強い硬化性変化が認められた。

（4）螺旋動脈の变性の高度㳊督杯で汸，結合織性硬 化像亡共に筋層心萎縮退化傾向が著明で, 腎杯壁び菲薄 化し，腎杯角或いはその他の部で龟裂を生じ，毛細血管 破総性出血を伴亏。

（5）各症例の全般的傾向として梐血性変化が著明で 法り, 特に出血部に於いては毛細血管の拱張, 漏出性出 血, 肉芽形成が見られた。

（6）以上の所見に基き, 特発性腎出血の 1 原因とし て, 蠌旋動脈の血行障害に起因した腎杯壁の一連の組織 变性が, 出血堂発生し易い場 (Locus minoris resistentiae) 学形成する点堂重頑すると共に, 腎血行障害特 に毛細血管圧克進因子の加入にょる毛細血管漏出性出 血, 並びに反復性出血の修復機轉及び血行障害による組 織の萎縮硬化性変化に基く毛細血管破綻性出血の $2 つ の$ 機轉を重要睍したい。

擱筆するに当り, 終始御懇篤なる御指導, 御鞭撻並び に御校閲を舓つた恩師黒田恭一教授に深甚なる感謝の意 を捧げます。文御教示を賜つた第 1 病理学教室梶川助教 授及び第 3 解剖学教室松田助教授, 並びに貴重な資料の 提供を戴いた国立金沢病院皮䖉科泌尿器科医長並木博士 に感謝致します。

本論文の要旨は第 47 回日本泌尿器科学会総会及び第 10 回同中部連合地方会に於いて発表した。

（本論交は金沢大学審査学位論文なることを附記す る).

\section{交献}

1) Nitze, M.: 皆見氏論文より引用.

2) Senator, H.: Zschr. Urol., 4, 542, 1910.

3) Klemperer, G.: Dtsch. med. Wschr., 129, 1897.

4) Israel, W.: Zschr. Urol., 23, 121, 1929.

5) Gottlieb, S.: Zschr. Urol., 20, 310, 1926.

6) Scheele, K. \& Klose, H.: Arch. Klin. Chir., 134, 388, 1925.

7）志賀亮, 小室秀一郎, 杉山万喜蔵：グレンッゲ ビート，12年，1327，1507，1938；13年，46， 157, 291, 1939.

8) Boeminghaus, H.: Dtsch. med. Wschr. 63, 559, 603, 1937.

9）藤田幸雄：石川医報， 125，2，1954.

10）新井网司雄：日泌尿会誌, 19，545，1930.

11) Chwalla, Rudolf: Zschr. Urol., 26, 449, 521, 1932.

12) Günther, G.W.: Zschr. Urol., 42, 42, 1947.

13）岡直友：臨床皮泌，9，1162，1955.

14）原田彰：泌尿紀要, 3, 481, 1957.

15) 仁平寛己：泌尿紀要，4，483，1958.

16) Ceelen, W.: Virchows Arch., 275, 675, 1929.

17) Kretschmer, H.L.: Zschr. Urol., 1, 490, 1907.

18) Casper: Zschr. Urol., 1, 85, 1907.

19) Rathbun, N.P.: Tr. Am. Gen.-Urin. Surg., 19, 253, 1926.

20) Silva, J.: XIc Congres de La Sociétéinternationale d'Urologie, p. 259, Stockholm, 1958.

21) Frauboes, R.: Zschr. Urol., 47, 65, 1954.

22) Sarre, H. \& Moench, A.: Zschr. exper. Med., 117, 49, 1951.

23) Griessmann, H. \& Eufinger, H.: Zschr. Urol., 45, 1, 1952.

24）山口与市: 最新医学, $10,366,1955$.

25）同上：慶応医学, 33, 213, 1956.

26) 同上：日本内科学会雑誌，45, 990, 1956.

27) 原田彰, 阔本重礼：日泌㽷会誌，48，306, 1957.

28）小川正見：日泌尿会誌，50，75，1959.

29) Thelen, A. \& Wiegers, H.: Arch. Klın. Chir., 277, 547, 1954.

30) Heine, J.: Zschr. Urol., 46, 247, 1953.

31) Finkel, L.A., Rrince, C.L. \&Scardino, P.L.: J. Urol., 72. 111, 1954.

32）島本治：日泌尿会誌，50，728，1959.

33) Young, E.L.: Surg. Gyne. \& Obst., 31, 478, 1920.

34) Braasch, W.F.: J.A.M.A., 61, 936, 1913.

35) Spitzer, W.M.: J.A.M.A., 63, 2110, 1914.

36) Fuchs, F.: Zschr. urol. Chir., 18. 164, 1925. 
37) Lewin, A.: Zschr. Urol., 16, 115, 1922.

38) Verliac: J. d' Urol. Paris., 17, 482, 1924.

39）新井嗣雄：日泌尿会誌, 19, 607, 1930.

40）原田彰, 岡本重礼, 笠井三郎：日本医事新報, No. 1856, 3, 1959.

41) Mac Mahon, H.E. \& Latorraca, R.: J. Urol., 71, 667, 1954.

42) Warsch, N.: Zschr. urol. Chir., 26, 339, 1929.

43) Miller, J. \& Young, D.H.: Canad. M.A.J., 24, 354, 1931.

44) Harlin, H.C.: J. Urol., 64, 445, 1950.

45) Alken, C.E. \& Hasche-Klünder, R.: Zschr. Urol., 45, 665, 1952.

46) Günther, G.W.: Helvet. Chir. Acta., 16, 407, 1949.

47) Günther, G.W.: Zschr. Urol., 42, 432, 1949.

48) Günther, G.W.: Zschr. Urol., 43, 20, 1950.

49）大野武司：日泌尿会誌，19，309，1930.

50）岩下健三：日泌尿会誌，27，182, 1938.

51 ）古沢太郎, 大越隆一：日泌尿会誌, 46,691 , 1955.

52） 巾拓磨：日泌尿会誌，49，686， 1958.

53) Martin, K.W.: Brit. J. Urol., 23, 233, 1951.

54) Nation, E.F., Butt, E.M., Massey, B.D. \& Gallup, C.A.: J. Urol., 68, 74, 1952.

55) Payne, R.L. \& Mac Nieder, W.B.: J.A.M. A., 67, 918, 1916.

56）清水圭三：日本医事新報, No. 1452, 17, 1952.

57）同上：日泌尿会誌, 47, 741, 1956.

58）原田彰, 岡本重礼：日泌尿会誌，48, 445, 1957.

59) Bogliolo, L. \& Silva, J.: Zschr. Urol., 47, 38, 1954.

60) Oberling, C.: Amer. J. Path., 20, 155, 1944.

61) Zimmermann, K.W.: Zschr. Mikro-anat. Forsch., 32, 176, 1933.

62) Becher, H.: Zschr. Wissensch. Mikro., 53, 205, 1937.

63 ) 过一郎：腎の平滑筋 (泌尿器科新書), 南江堂, 東京, 京都, 1953.

64) Narath, P.A.: Campbell; Urology, Vol.
1, p. 61 , W.B. Sunders Co., Philadellphia \& London, 1954.

65）江口秀雄 : 日病会誌, 47, 323, 1958.

66) Spanner, R.: Klin. Wschr., 16, 1421, 1937.

67) Baker, S.B. de C.: Brit. J.Urol., 31, 53, 1959.

68）医学のあゆみ，14，115，1952.

69) Reynold, S.R.M.: Am. J. Obst \& Gynec., 53, 221, 1947.

70) Tobin, C.F.: Surg. Gynec \& Obst., 95, 741, 1952.

71) Quinby, W.C.: J. Urol., 4, 209, 1920.

72) Mc Kay, H.W.. Baird, H. \& Lynch, K.M., Jr.: J.Urol., 61, 1, 1949.

73）堀尾博：日泌尿会誌，34，228，1943.

74) Schranz: Zschr. Urol., 17, 513, 1923.

75）黑田信夫：日皮会誌，28，682, 1928.

76）木根淵善吉：日泌尿会誌，30，189，1941.

77) Bumpus, Hermon, C., Jr.: J.A.M.A., 90, 593, 1928.

78）武田勝男: 新病理学総論, p. 154, 南江堂, 東 京, 1957.

79) Schuppel, A.: Zschr. Urol., 16, 201, 1922.

80) Rumpel, O.: Zbl. Chir., 54, 897, 1927.

81）新井嗣雄：日泌尿会誌， 19，588，1930.

82) Randall, A.: J. Urol., 37, 735, 1937.

83）中山惠夫, 材崎勉：日泌尿会䛱，41，226, 1950.

84）皆見省吾，藤原皓：日泌尿会誌， 17, 1, 1928 .

85）諏訪紀夫：最新医学，10，632，1955.

86) Günther, G.W.: Zschr. Urol., 42, 174, 1949.

87）荒木康雄：日病会誌，47,692，1958.

88) 西丸和義: 毛細脈管の研究 (綜合医学新書), No. 3, 日本医学雑誌株式会社, 東京, 1949.

89) 渋沢喜守雄, 丹後淳平, 西沢康男: 無尿々圭尿 一急性腎不全一, 医学書院, 東京・大阪, 1959.

90) 高安久雄, 伊藤一元, 馬場弘二郎 : 最新医学, 10, 1195, 1955.

91）永田正夫, 徳田安之助, 高村武次：蹦床皮泌, 10, 359, 1956.

92) 田村裕治, 椎木茂雄, 須藤俤次: 䠦束皮泌, 12, 1315, 1958. 